\title{
SAVIVALĖS PROBLEMA LIETUVOS KARIUOMENĖS DRAUSMĖS BATALIONE VARNIUOSE 1921-1922 M.
}

\author{
Dr. Modestas Kuodys \\ Vytauto Didžiojo universitetas
}

\section{IVADAS}

Žodžių junginys „drausmès batalionas“ (arba „drausmès kuopa“) šiandien dažnam bent šiek tiek nusimanančiam apie naujausiųjų laikų pasaulio istoriją skaitytojui pirmiausia asocijuotųsi su Sovietų Sąjungos Raudonosios armijos kariais, 1941-1944 m. vadovybès siųstais ị pačią baisiausią Rytų fronto mėsmalę, kad „krauju išpirktų“ tikras ar menamas kaltes „valstybei ir liaudžiai“" Kiek mažiau žinoma, jog panašią bausmės formą (tik ne taip beatodairiškai ir beprasmiškai) tuo metu praktikavo ir vokiečiai ${ }^{2}$. Vis dèlto XX a. pirmoje puseje specialūs drausmès daliniai nebuvo jokia naujiena. Pirmojo ir Antrojo pasaulinių karų metu įvairiose šalyse jiems dažniausiai tekdavo pačios pavojingiausios užduotys, o per trumpą tarpukario taikos periodą - kareivių drausminimo funkcijos. Pastarosios buvo aktualios ir Nepriklausomos Lietuvos (1919-1940 m.) kariuomenei. Tiesa, čia „savarankiškas“ drausmei skiepyti skirtas karinis dalinys, kelissyk transformavęsis nuo bataliono iki kuopos ir atvirkščiai, egzistavo palyginti trumpai - tik 1920-1928 m. Nepaisant to, jis, kaip ir užsienio analogai, „suspejjo“ užsitarnauti atgrasią reputaciją. Tai neturètų stebinti: pasku-

\footnotetext{
1 Reese R. R., The Soviet Military Experience. A History of the Soviet Army, 1917-1991, London and New York: Routledge, 2001, p. 115-116.

2 Vermachto veteranų liudijimu, išsiuntimas ị drausmės dalinị Rytų fronte buvo viena iš baisiausių bausmių. Kad to išvengtų, kareiviai buvo pasiryžę ištverti sunkiausius mokymus, nedrịsdavo net pagalvoti nepaklusti vadų įsakymams. Žr.: Sajer G., Užmirštas kareivis, Kaunas: Vox altera, 2013, p. 167, 170.
} 
bomis kuriamose Lietuvos ginkluotosiose pajègose ir dar karo padèties sąlygomis net ir griebiantis skrupulingos kontrolès didesnių ir mažesnių ekscesų vargu ar buvo įmanoma išvengti. Jų ir neišvengta, tačiau siekta pasimokyti iš klaidų, užkirsti kelią negatyviems reiškiniams ateityje. Šis straipsnis yra apie vieną tokią išmoktą sunkią pamoką - šokiruojančios situacijos, susidariusios 1921-1922 m. Varnių miestelyje dislokuotame Drausmės batalione, išaiškinimą ir priimtus sprendimus. Tai, kas ten vyko, ko gero, galètų būti vadinama pačia juodžiausia dème jaunos demokratinès Lietuvos kariuomenès istorijoje. Tačiau dèl ryžtingų teisinių veiksmų, karo cenzūros ir kitų slaptumo priemonių ji nevirto plačiai nuskambejjusiu skandalu. Tokiu būdu užsitikrinta ramybė viešojoje erdvejje sudarè sąlygas siekti tvarių teigiamų permainų. Nesiblaškant, veikiant kryptingai, ilgainiui Lietuvos kariuomenėje pavyko tarp savivalés ir elementarių žmogaus teisių nubrèžti aiškią ribą - per vẻlesnius aštuoniolika šalies Nepriklausomybès metų ji daugiau nė karto nebuvo taip šiurkščiai pažeista. Tad, atrodytų, kokia gi prasmè iš užmaršties kelti tai, apie ką net patys amžininkai nedaug težinojo (ar nutylèdavo, norèdami kuo greičiau pamiršti), ką skelbè tik juoda demagogija pagarsėjęs antivalstybinis pogrindis, o vèliau tokios pat padermès sovietine istoriografija? Atsakymas i panašius retorinius klausimus jau ne kartą îvairiomis progomis ir ịvairiose vietose buvo pateiktas: istorinès tiesos, kad ir kokios nemalonios, paieškos, leidžia išvengti skaudžių klaidų, jų nebekartoti, padeda atremti tendencingas propagandines insinuacijas ir apskritai skatina visuomenès pilietinị sąmoningumą, brandą. Savaime suprantama, kad praeitis yra tokia pat sudetinga, nevienareikšmiška, kaip ir dabartis - joje galima rasti ne tik herojiškų, pasididžiavimo vertų, bet ir visiškai priešingus jausmus keliančių epizodų.

Šio straipsnio tikslas - remiantis iki šiol ị mokslo apyvartą nepatekusia medžiaga, îvertinti Lietuvos kariuomenès Drausmès batalione Varniuose 1921-1922 m. susidariusią kontroversišką situaciją, parodyti, kaip ji buvo tiriama ir normalizuojama. Šiam tikslui pasiekti iškelti trys uždaviniai:

1) Atskleisti Lietuvos kariuomenès Drausmès bataliono, kaip karinio dalinio, specifiką.

2) Išryškinti savivalès Drausmès batalione baudžiant atsiųstus kareivius 1921-1922 m. pobūdị.

3) Apibendrinti informaciją apie $1922 \mathrm{~m}$. Drausmès batalione atlikto 
tyrimo padarinius šio dalinio vadui.

Kiekvienas iš šių trijų uždavinių yra nuosekliai susijęs su konkrečiu straipsnio skyriumi.

Tyrimo chronologinès ribos - 1921-1922 m., laikotarpis, kai Lietuvos kariuomenès Drausmès batalionas buvo dislokuotas Varniuose ir jo veikloje issivyravo neteisèta elgesio su drausmines bausmes atliekančiais kareiviais praktika. Krašto apsaugos ministeriją (toliau - KAM) informacija apie tai pasiekè $1921 \mathrm{~m}$. viduryje - tada prasidejo patikros ir kruopštus tyrimas, pasibaigęs $1922 \mathrm{~m}$. rudenị. Vis dèlto šia trumpa laiko atkarpa straipsnyje griežtai neapsiribojama: siekiant sudaryti išsamesnį vaizdą, glaustai pristatoma ir dalinio genezė 1920 m., taip pat kai kurie svarbesni jo raidos per vèlesnius šešerius metus faktai.

Mokslinès literatūros pasirinkta nagrinèti tema beveik nèra. Iš sovietmečiu paskelbtų darbų paminèti verta tik Eusiejaus Jacovskio monografiją apie „buržuazinès“ Lietuvos kalèjimus ir kitas „teroro politikos“ apraiškas 3 . Savivalès Drausmès batalione 1921-1922 m. istorija knygoje, suprantama, buvo panaudota beatodairiškam Nepriklausomos Lietuvos kariuomenès juodinimui. Tvirtinta, kad i privalomąją karo tarnybą pašaukti „susipratę darbo liaudies sūnūs“ sadistiškais būdais buvo drausminami visą „išnaudotojų klasès“ viešpatavimo dvidešimtmetị. Taip vieną kontroversišką epizodą pasistengta paversti vienareikšmišku apibendrinimu.

Ne tik išeivijoje, bet Nepriklausomybę susigrąžinusioje Lietuvoje ekscesų Drausmès batalione 1921-1922 m. problematika atskiro tyrẻjų dèmesio nesulaukè. Galima išskirti vos keletą kontekstinès reikšmès istoriografijos pozicijų. Glaustus duomenis apie Drausmès dalinio pirmtakès Atsargos kuopos ịsteigimą 1920 m. savo knygoje pateikè Vytautas Lesčius ${ }^{4}$. Kur kas nuodugniau karių baudimo praktiką Nepriklausomos Lietuvos kariuomenėje apžvelgè Andriejus Stoliarovas išsamiame straipsnyje apie 1921-1940 m. Kaune (VI forte) veikusị Karo kalèjimą ${ }^{5}$ ir kiek vèliau

\footnotetext{
3 Žr.: Jacovskis E., Už grotų. Iš buržuazinès Lietuvos kalejimo istorijos, Vilnius: Mintis, 1965, p. 149-151.

4 Lesčius V., Lietuvos kariuomenè 1918-1920, Vilnius: Leidybos centras, 1998, p. 149-150.

5 Stoliarovas A., Karo kalejjimas Kaune 1921-1940 metais // Kauno istorijos metraštis, t. 13, Kaunas: Vytauto Didžiojo universitetas, 2013, p. 117-130.
} 
publikuotoje mokslineje monografijoje $e^{6}$, skirtoje visapusei tuometès karinès teismu sistemos analizei. Tačiau Drausmès kuopos (bataliono) veikla šiuose darbuose aptarta tik bendrais bruožais - ivertinant oficialiuosius reglamentus, nes tai nebuvo jų autorių pagrindinis tikslas.

Labai negausią mokslinejje literatūroje pateiktą informaciją apie Lietuvos kariuomenès Drausmès batalioną pirmoje XX a. trečiojo dešimtmečio pusėje šiek tiek papildo keli publikuoti šaltiniai. Išsamiausias iš jų - 1928 m. „Mūsų žinyne“ paskelbtas vieno iš buvusio Drausmès bataliono karininkų - mjr. Henriko Šalkausko ${ }^{7}$ keturių puslapių apimties straipsnis ${ }^{8}$, kuriame pristatoma dalinio raida 1920-1926 m. Pažymètina, jog autorius né puse žodžio neužsiminė apie 1921-1922 m. brendusị skandalą, nors archyviniai dokumentai rodo, kad tai jam negalèjo būti nežinoma. Straipsnyje karininkas daugiausia aprašo, kaip buvo sprendžiami rutininiai ūkiniai klausimai daliniui kuriantis Varniuose, organizuojamas kareivių mokymas, švietimas, improvizuotas šventes (sporto ir kitas pramogas, kurių dalyviai buvo skatinami prizais) taip, tarsi pasakotų apie pačios paprasčiausios pėstininkų kuopos kasdienị gyvenimą. Kontroversiški dalykai buvo sąmoningai nutylèti. Apskritai visoje šalies legalioje spaudo-

6 Stoliarovas A., Lietuvos Respublikos karine justicija 1919-1940 m., Kaunas: Vytauto Didžiojo karo muziejus, 2014.

7 1921-1923 m. dokumentuose jo vardas ir pavardè rašomi skirtingai - neretai Genrichas Salkauskas, kartais - Šalkauskas. Šis asmuo gime 1895 m. spalio 14 d. Joniškyje (Šiaulių apskrityje), mokèsi Šiaulių gimnazijoje, $1915 \mathrm{~m}$. buvo mobilizuotas ị Rusijos kariuomenę, baige Žitomyro praporščikų mokyklą ir Rumunijos fronte sulauke 1917 m. Rusiją apėmus pilietiniam karui, 1919 m. rudeni grịžo ị Lietuvą. 1920 m. pradžioje buvo mobilizuotas į Lietuvos kariuomenę, gavęs vyr. ltn. laipsnị, tarnavo karininku 4-ajame pèstininkų pulke, dalyvavo Nepriklausomybès kovose su lenkais.1921 m. birželio $9 \mathrm{~d}$. buvo paskirtas Drausmès bataliono vado padejejju, o tų pačių metų spalio $1 \mathrm{~d}$. tapo vienos iš bataliono kuopų vadu. 1921-1923 m. èjo šio bataliono vado pareigas (1922 m. gegužès 18 d. suteiktas kapitono laipsnis). Drausmès batalioną reorganizavus ị kuopą, $1926 \mathrm{~m}$. sausio $1 \mathrm{~d}$. paskirtas jos vadu (1927 m. vasario $16 \mathrm{~d}$. pakeltas i majorus).1928 m. baige Aukštųjų karininkų Didžiojo Lietuvos kunigaikščio Vytauto kursų bendrąji skyrių (VII laidą). 1929 m. sausio 28 d. buvo išleistas ị atsargą, 1940 m. ejo Kauno sunkiųjų darbų kalejimo viršininko pareigas. Sovietinès okupacijos pradžioje buvo suimtas, nuteistas ir išvežtas i priverčiamojo darbo stovyklą. Žuvo 1949 m. Vorkutoje. Žr.: Lietuvos kariuomenés karininkai 1918-1953, t. 7, Vilnius: Lietuvos nacionalinis muziejus, 2007, p. 251.

8 Šalkauskas H., Drausmès kuopa (1920-1926 m.) // Mūsu žinynas, 1928, Nr. 45, p. 383-385. 
je 1922 m. Drausmès batalione nustatyti karininkų savivalès faktai bent kiek ryškesnių komentarų nesulaukè. Tik pogrindinė Lietuvos komunistų partija (toliau - LKP), nors ir gerokai pavėlavusi, stengėsi tą kariuomenę diskredituojančią informaciją panaudoti propagandai ${ }^{9}$.

Informacijos apie Varniuose dislokuoto Drausmès bataliono bylą yra ir emigracijoje parašytuose Jono Polovinsko-Budrio, kuris XX a. trečiojo dešimtmečio pradžioje vadovavo Lietuvos karinei kontržvalgybai, atsiminimuose $^{10}$. Ši institucija prisidejo tiriant situaciją Varniuose. Todèl J. Budrys 1922 m. buvo pakviestas liudyti Drausmès bataliono vado teisme. Atsiminimuose jis trumpai apibendrino šio teismo aplinkybes ir baigti.

Paties ikiteisminio tyrimo eigą igalino atskleisti Lietuvos centriniame valstybės archyve rasti dokumentai. Pažymėtina, kad nemažai jų buvo sunkiai ịskaitomi, nes rašyti ranka (ir anaiptol ne kaligrafiškai), raidžių rašalas pablukęs. Vis dèlto būtent šios rūšies šaltiniai sudaro straipsnio faktografinị pagrindą. Pirmiausia paminètinas Drausmès kuopos fondas (f. 763). Vertingiausi jame - dalinio vado vyr. ltn. Jurgio Nevronio ${ }^{11}$ isakymai, iš kurių galima spręsti apie bendrąją vidaus tvarką, ją trikdžiusias problemas ir pan. Sykiu teko išstudijuoti ir šio karininko asmens bylą, saugomą 930 fonde (KAM ìstaigų ir karinių dalinių asmens sudèties dokumentų kolekcijoje), kurioje susegti jo atestacijos lapai ir kitos tarnybos eigos pažymos. Dauguma liudininkų apklausų protokolų apie savivalę Drausmès batalione saugomi Kariuomenès teismo fonde (f. 507). Ivairaus pobūdžio dokumentų, susijusių su minètais kontroversiškais 1921-1922 m. įvykiais Varniuose, taip pat pavyko rasti Vietinès kariuomenès brigados (f. 10) ir kai kuriuose kituose fonduose. Archyve surinkta medžiaga išryškino tamsius nemalonios istorijos kontūrus. Tačiau reikia pabrèžti, kad pats jos pristatymas straipsnyje yra individuali autoriaus interpretacija, dèl rastų duomenų ribotumo ir žmogiškųjų klaidų tikimybės nepretenduojanti ị "galutinę tiesą".

9 Žr.: Kareivių kankinimas // Kareivių tiesa, 1924, Nr. 1, p. 2-3.

10 Budrys J., Kontržvalgyba Lietuvoje, fotograf. leid., Vilnius: Žaltvykslè, 1991, p. $182-187$.

11 Šio karininko pavardė dokumentuose rašoma nevienodai - XX a. trečiojo dešimtmečio pirmoje pusejje - Nevronis, ketvirtajame dešimtmetyje neretai - Niauronis. 


\section{BENDROJI INFORMACIJA}

Prieš pradedant nagrinèti 1921-1922 m. Lietuvos kariuomenès Drausmès batalione susidariusią situaciją prasminga bendrais bruožais pristatyti svarbiausius faktus, susijusius su jo atsiradimu ir specifika.

Vienintelio „oficialaus“ straipsnio apie šị dalinị autorius mjr. H. Šalkauskas pažymèjo, kad jo įsteigimą lèmé 1920 m. vasario 22-23 d. Kauno iguloje kilę neramumai - reikèjo kažkur izoliuoti, atidžiau prižiūrèti ir pabandyti perauklèti potencialiai pavojingus valstybei, nedrausmingus ar kitaip nusikaltusius kareivius ${ }^{12}$. Šj daug rūpesčių keliantị kontingentą pradèta siųsti ị tų pačių metų gegužès $1 \mathrm{~d}$. Kauno priemiestyje, Aukštojoje Panemuneje, suformuotą Atsargos kuopą. Vadu buvo paskirtas vyr. ltn. Jurgis Nevronis ${ }^{13}$ - jis per dvejus vèlesnius metus tapo centrine figūra kontroversiškoje šio dalinio istorijoje. Visa tai vyko sudetingu Lietuvos kariuomenès kūrimosi laikotarpiu, kai reikèjo būti pasirengus stoti ị kovą už šalies Nepriklausomybę, o kariams trūko ginklų, aprangos,

12 Šalkauskas H., min. str., p. 383.1920 m. gegužès 27 d. buvo paskelbti „Atsargos kuopos bendrieji dèsniai“, juose dalinio paskirtis apibūdinta su tam tikru rafinuotu idealistiniu polèkiu: „Turint omenyje, kad kareivių didžiuma nusižengia kariškai drausmei ne dèl igimto patraukimo prie piktų darbų, bet dèl blogo auklejjimo ir valios silpnumo, reikalinga labiau linkusius prasižengti ịstatymams kariškos drausmès kareivius izoliuoti ir priversti išeiti tam tikrą mokyklą. Kareivị reikia sudominti fiziniais mankštinimais ir mokslu, neužgrūsti ji vien tik karo muštru ir statutų kalimu, reikia išaiškinti gyvenimo tvarką ir minties logiką, užinteresuoti sportu, amatais, būtinumu darbo, tvarkos, drausmès ir ištvermès.“: Atsargos kuopos bendrieji dèsniai // İsakymas kariuomenei Nr. 343, 1920 m. gegužès 27 d., Kaunas, Rikiuotès skyrius.

13 J. Nevronis gimè 1893 m. vasario 21 d. tuometès Biržų-Pasvalio apskrities Pušaloto valsčiaus Gikonių kaime. Baigè šešias klases Panevėžio realinèje, o septintąją - Petro I gimnazijoje Rygoje. Nuo 1913 m. tarnavo Rusijos kariuomenejje, artilerijos daliniuose, tobulinosi pirotechnikų kursuose. 1917 m. rugsejo 6 d. baige Maskvos I praporščikų mokyklą ir buvo pakeltas it podporučikus. Po bolševikų perversmo Rusijoje prasidejus pilietiniam karui pasitrauke ị Latviją. Šios jaunos valstybès kariuomenès artilerijos dalinyje tarnavo nuo 1919 m. rugsejo $10 \mathrm{~d}$. iki lapkričio 8 d. Po to grị̌zo ị Lietuvą ir $1919 \mathrm{~m}$. gruodžio $2 \mathrm{~d}$. buvo mobilizuotas ị jos kariuomenę. Pradejo tarnauti 2-ajame atsargos batalione. Tų pačių metų gruodžio 20 d. J. Nevroniui buvo suteiktas vyresniojo leitenanto laipsnis. 1920 m. kovo $15 \mathrm{~d}$. jis buvo perkeltas ị Karo mokyklą, o iš ten - tų pačių metų gegužès 1 d. - i Drausmès kuopą, paskirtas jos vadu. Žr.: Vyr. ltn. J. Nevronio tarnybos lapas, 1924 m. // LCVA, f. 930, ap. 2N., b. 55, 1. 1-3. 
visaverčio maisto, patalpų. Su šiais sunkumais susidūrè ir Atsargos kuopa. Kaip iš nevisiškai patikimų kareivių sudarytas dalinys, ji negalejjo tikètis ypatingo kariuomenès vadovybès demesio ir bent kiek geresnio aprūpinimo. Ilgą laiką neturejo ir nuolatinès dislokacijos vietos. $1920 \mathrm{~m}$. birželio pradžioje kuopai teko persikelti ị Kalvariją (Sūduvos regione). Tačiau čia, neradus tinkamų patalpų, buvo perkelta i Vilkaviški, vẻliau - i Panevėži (iš pradžių apsistojo pačiame mieste, paskui persikèlè ị netoli jo buvusị Liudynès dvarą).

1920 m. spalio viduryje i Lietuvą besiveržiant „maištaujančiai“ lenkų kariuomenei, patikimas 50 vyrų Atsargos kuopos būrys buvo priskirtas prie Utenos miesto ir apskrities karo komendantūros - talkino jai stabdant prasiveržusią lenkų kavaleriją ${ }^{14}$. Spalio 25 d. Atsargos kuopa buvo pavadinta Drausmès kuopa. Netrukus jai teko palikti Panevėži. Pagrindinè priežastis - Liudynès dvare kilęs gaisras, nuniokojęs daug gyvenamųjų patalpų. 1920 m. gruodžio pabaigoje kuopoje tarnavo 3 karininkai, 1 karo valdininkas, 1 gydytojas ir 119 kareivių $^{15}$. Kitų metų pavasarị Drausmès kuopa sulauke įsakymo persikelti $\mathfrak{i}$ atokų Vakarų Lietuvos miestelị - Varnius. Tuo metu tai buvo pats tikriausias užkampis. Nuo artimiausio apskrities centro Telšių jị skyrè maždaug 30 kilometrų atstumas, kurị ịveikti tekdavo pėsčiomis arba arkliais kinkytais vežimais. Bet pastarųjų kariams gauti buvo nelengva, nes kariuomenès vadovybė neleido be rimtos priežasties varginti ūkininkų reikalavimais pavéžèti ${ }^{16}$.

1921 m. balandžio 25 d. atvykusi ị Varnius Drausmès kuopa pradejjo kurtis gerokai apgriuvusiuose buvusios Žemaičių dvasinès seminarijos rūmuose ir pagalbiniuose pastatuose ${ }^{17}$, kuriuose prieš Pirmąji pasaulinị karą šeimininkavo Rusijos kariuomenės kazokų dalinys. Kaizerinės okupacijos metais čia kareivines buvo įsirengę vokiečiai. Traukdamiesi iš Lietuvos, jie išgrobstė daug ịvairaus turto, nusiaubė patalpas. Kai kuriose iš jų apsigy-

\footnotetext{
14 Šalkauskas H., min. str., p. 383.

15 Lesčius V., min. veik., p. 150.

161922 m. pradžioje Varnių valsčiaus valdyba skundèsi dažnais bataliono vadovybès reikalavimais parūpinti jiems vežimų su arkliais ir bandymais užkrauti kitas panašaus pobūdžio prievoles. 1922 m. KAM Generalinio štabo Žvalgybos skyriaus pažyma // LCVA, f. 10, ap. 1, b. 124, 1. 58 .

$171921 \mathrm{~m}$. spalio 9 d. Vietinès kariuomenès brigadai įsakymas Nr. 77 // LCVA, f. 10, ap. 1, b. $35,1.404$.
} 
veno vargingi apylinkių žmonès ${ }^{18}$. Tad Drausmès kuopos vadovybei teko nedelsiant imtis organizuoti remonto ir statybos darbus. Lèšų tam turèta labai nedaug, tačiau, ịsigijus būtiniausių medžiagų, daug ką atliko patys kareiviai. Vis dèlto pirmaisiais metais Drausmès kuopos „buveinë“ nelabai atitiko kariniam daliniui skirtos teritorijos reikalavimus - perimetras nebuvo tinkamai aptvertas, pastatus ir šalia jų esančią žemę vis dar teko „dalintis“ su miestelènais. Ne tik statybines medžiagas, bet iš pradžių ir maisto produktus kuopa turẻdavo atsigabenti iš Telšių arba net Šiaulių ${ }^{19}$. Per šị miestą tuo metu vyko susisiekimas ir su Kaunu. I dalinị siunčiamų kareivių skaičius nuolat augo, todèl $1921 \mathrm{~m}$. rugpjūčio $1 \mathrm{~d}$. jis buvo reorganizuotas ị batalioną ${ }^{20}$. Drausmès batalionas, kaip iki tol Atsargos ir Drausmès kuopos, buvo Vietinès kariuomenès brigados dalis. Pastarajai tuo metu priklausė visos miestų ir apskričių karo komendantūros, koncentracijos $^{21}$ ir belaisviu stovyklos. Kol buvo dislokuotas Varniuose (iki 1926 m.), batalionas priklausė Antrajai karo apygardai (vèliau karo apygardos pavadintos divizijomis).

Atrodo, kad apie $1921 \mathrm{~m}$. buvo parengti ir „Drausmés bataliono bendrieji dèsniai“ (t. y. savotiški ịstatai) ${ }^{22}$. Jie nelabai skyrèsi nuo Atsargos kuopos veiklą reglamentavusio panašiai pavadinto dokumento. „Bendrųjų dèsnių“ pirmame punkte nurodyta, kad svarbiausias dalinio uždavinys „auklèti ir mokinti drausmèje kareivius, paskirtus 1) atlikti karo teismo

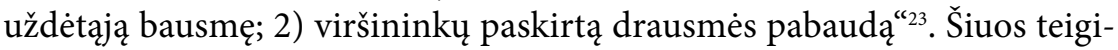
nius būtina šiek tiek patikslinti. Karo, arba karo lauko, teismas tuo metu (esant paskelbtai karo padéčiai) būdavo sudaromas laikinai, pagreitinta ir

18 Karininko ypatingiesiems reikalams prie KAM plk. Vinco Grigaliūno-Glovackio 1921 m. spalio 1 d. raporto KAM nuorašas // LCVA, f. 507, ap. 6, b. 1816, 1. 50.

19 Ten pat, 1. 45.

$201921 \mathrm{~m}$. rugpjūčio $2 \mathrm{~d}$. batalione buvo 212, o beveik po dviejų mėnesių - jau 365 kareiviai. Žr.: $1921 \mathrm{~m}$. rugpjūčio $2 \mathrm{~d}$. ir rugsèjo $25 \mathrm{~d}$. Drausmès bataliono vado ịsakymai // LCVA, f. 763, ap. 1, b. 17, 1. 414, 516.

21 Antivalstybine veikla įtariami civiliai asmenys 1920-1923 m. buvo izoliuojami Kaune (Aukštojoje Fredoje) veikusioje koncentracijos stovykloje. Žr.: Kuodys M., Varniai, Dimitravas, Pabrade: koncentracijos ir priverčiamojo darbo stovyklos Lietuvoje 1927-1940 m., Vilnius: Versus aureus, 2007, p. 22-35.

$221921 \mathrm{~m}$. Drausmès bataliono bendrieji dèsniai // LCVA, f. 763, ap. 1, b. 135, 1. 1-8.

23 Ten pat, 1. 1. 
supaprastinta tvarka sunkiems karių ir civilių nusikaltimams nagrinèti. Mus dominančiu atveju karo teismo funkcijas atlikdavo „žemiausios instancijos" - pulkų teismai, nagrinèję nedidelius karių padarytus nusikaltimus. Retais atvejais tuo užsiimdavo ir centrinė Lietuvos Respublikos karinès teismų sistemos ašis - Kaune nuolat veikęs Armijos (Kariuomenès) teismas, nors jo kompetencijai „smulkios“ bylos paprastai nepriklausydavo $^{24}$. Kareivių atidavimo į drausmès dalinị sąlygos ir tvarka buvo nustatyta remiantis Lietuvos situacijai adaptuota 1869 m. Rusijos imperijos karinių isstatymų sąvado XVII knyga, jos papildymais ir pakeitimais, atliktais iki 1907 m. ${ }^{25}$

Dalis kareivių Drausmès batalione atsidurdavo be jokio teisminio kaltès ịrodinejjimo - vien jų dalinio vadovybès sprendimu ${ }^{26}$. Tiesa, labai dažnai tokị sprendimą tiesiogiai inicijuodavo Lietuvos kariuomenès kontržvalgyba, įtarusi, kad vienas ar kitas kareivis kaip nors susijęs su antivalstybiniu pogrindžiu. Dèl tokios praktikos nestigo skundų. Antai $1921 \mathrm{~m}$. rugsèjo 15-16 d., Drausmès bataliono inspekcijos metu, net 107 kareiviai pareiškè, kad yra nubausti nepagrịstai, nes pateikti kaltinimai - kontržvalgybos prasimanymai ${ }^{27}$. Tiesa, panašių skundų nereikètų vertinti vienareikšmiškai, mat Lietuvos komunistų partijos nariai ar aktyvūs jos rèmėjai sučiupti dažnai sąmoningai laikèsi garsiai rèkiančios „nekaltos aukos“ taktikos.

Prieš siųsdami karius ł̇ Drausmès batalioną pulkų vadai privalèjo pasiteirauti, ar yra laisvų vietų. Tik gavę patvirtinimą, galèjo pradèti organizuoti problemiško asmens išsiuntimą (iš pulko sąrašų jis nebuvo išbraukiamas, nes, atlikęs bausmę, turejjo grižti ị pradinę tarnybos vietą). Be to, kartu reikejo pateikti skirtos bausmè pagrindimą.

Drausmės bataliono žmogiškieji ištekliai (vidutiniškai apie 350-370 karių) oficialiai buvo suskirstyti ị dvi aiškiai skirtingas grupes. Pirmoji doku-

24 Išsamiai apie Lietuvos Respublikos karo teismų pavadinimų kaitą, kompetencijos ribas, tarpusavio sąveiką. Žr.: Stoliarovas A., min. veik., p. 27-119.

25 Isakymas kariuomenei Nr. 480, 1920 m. lapkričio 14 d., Kaunas, Rikiuotès skyrius.

26 Tokia teisè buvo numatyta $1920 \mathrm{~m}$. lietuvių kalba išleistame Drausmès statute. Žr.: Drausmés statutas, Kaunas: KAM, 1920, p. 3. Sprendžiant iš 1921 m. įsakymuose Drausmès batalionui figūruojančių duomenų, be teismo ị dalinị bausmès atlikti patekdavo tik apie trečdalis ar šiek tiek daugiau kareivių. Žr.: LCVA, f. 763, ap. 1, b. 17.

271921 m. rugsèjo 15-16 d. Drausmès bataliono inspekcijos metu užregistruoti „keičiamosios" sudèties kareivių skundai // LCVA, f. 507, ap. 6, b. 1816, 1. 246-253. 
mentuose vadinta „kadro“ arba „nuolatine“ dalimi - ją sudare karininkai, puskarininkiai, karo valdininkai ir ị ši dalini paskirti šauktiniai. Tai buvo Drausmės bataliono, kaip nusikaltusių kareivių perauklejjimo dalinio, etatinis personalas - vadovybè, prižiūrètojai (vidutiniškai apie 100-120 žmonių). Sargų pareigas einantys kareiviai, apmokyti kaip karo milicininkai, sudarè bataliono komandą, jai vadovavo komendantas. Pastarojo žinioje buvo bataliono daboklè.

Kita - maždaug dvigubai gausesnè - dalis, dokumentuose vadinta „keičiamąja sudètimi“, - iš ịvairiose Lietuvos vietose dislokuotų pulkų bausmès atlikti atsiųsti šauktiniai. Pastarieji pagal nusižengimų pobūdị skirstyti ị tris kategorijas: 1) patekę ị Drausmès batalioną už agitaciją, „triukšmavimą“ ir kitą ǐžūlų, provokuojamą elgesį; 2) vagišiai; 3) dezertyrai ${ }^{28}$. Trečiosios kategorijos atstovų Varniuose atsidurdavo daugiausiai ${ }^{29}$. Ir tai nestebina savavališkas pasitraukimas iš tarnybos arba slapstymasis nuo mobilizacijos pirmaisiais Lietuvos kariuomenės gyvavimo metais buvo gana paplitęs reiškinys. Vien 1920 m. miestų ir apskričių karo komendantūros užregistravo daugiau kaip 5 tūkstančius sučiuptų tokių vyrų ${ }^{30}$. I Drausmès batalioną kareiviai buvo siunčiami ilgesniam nei dviejų mėnesių laikotarpiui. Nepasitaisiusiems bausmès laikas galèjo būti pratęstas. Tai nuspręsdavo komisija, sudaryta iš bataliono karininkų ir puskarininkių.

„Drausmès bataliono bendrieji dèsniai“ skelbè, kad iš sąrašų „keičiamosios sudèties" kareivis gali būti išbrauktas tik atlikęs bausmę, po mirties arba pasibaigus tarnybos laikui, bet pastaruoju atveju likusią bausmès dali - jau kaip civiliui - jam tekdavo atsèdèti paprastame kalejjime. Tokia perspektyva dažnam nubaustajam neatrode geresnè. Kai kas dèl to puldavo net ị neviltị. 1923 m. rudenị laikinai ejjęs Drausmès bataliono vado pareigas kpt. Pranas Saladžius savo raporte II pėstininkų divizijos vadui nupasakojo paradoksalią situaciją: „Kuomet prisiejjo siųsti į kalèjimą pirmąją partiją, kareiviai sueję prašè, kiti net ašarodami, nesiųsti ị kalejjimą, bet duoti jiems daugiau darbo, ilgiau laikyti batalione. Aiškinosi, kad jie

\footnotetext{
$281921 \mathrm{~m}$. Drausmès bataliono bendrieji dèsniai..., 1. 2.

29 Šalkauskas H., min. str., p. 386.

30 Pacevičius P., Lietuvos kariuomenès dezertyrai Nepriklausomybès karų ir valstybingumo ittvirtinimo laikotarpiu 1918-1923 m. // Karo archyvas, t. 29, Vilnius: Generolo Jono Žemaičio Lietuvos karo akademija, 2014, p. 75.
} 
nori būti kareiviais ir grịžt namo kareiviais, tik ne kaliniais. Jiems būsią gèda savo kaime ir pasirodyti. Kiti aiškinosi, kad savo apskrities mieste teksią būti kalëjime, kur matysią pažistami juos kaliniais esant."31

Beje, $1921 \mathrm{~m}$. „Drausmès bataliono bendruosiuose dèsniuose“ buvo numatyta ir dar viena, tiesa, labai savotiška sąlyga, suteikianti teisę būti išbrauktam iš „keičiamųjų“ sąrašo. Ji turejo būti pritaikyta kareiviams, pabėgusiems iš Varniuose dislokuoto dalinio ir nesučiuptiems du ménesius $^{32}$. Archyviniuose dokumentuose nepavyko rasti duomenų, ar tokių sẻkmingų bėglių pasitaiké, bet apskritai pabėgimų būta gana dažnai. Beveik kiekviename $1921 \mathrm{~m}$. bataliono vado įsakyme užsimenama apie kelis pabègusius karius.

Nesunku numanyti, kad „kadro“ ir „keičiamosios sudèties“ kareivių gyvenimo sąlygos ir režimas skyrèsi. Pirmieji naudojosi tokiomis pat teisėmis kaip ir visi kiti Lietuvos kariuomenès šauktiniai, privalèjo išeiti tą patị bazini kario rengimo kursą ir t. t. Tačiau jie dar turèjo ir tam tikrų „privilegijų“ - pagal pinigines išmokas buvo „prilyginami specialistams ${ }^{\text {“ }}{ }_{33}$. „Keičiamosios sudèties“ kariai ne tik negaudavo išmokų, bet ir jų asmeninių lèšų naudojimas buvo griežtai ribotas. Skyrèsi ir maisto davinys ${ }^{34}$. Sargybiniai buvo maitinami ne blogiau (o kai kada gal ir geriau) nei kitu daliniu kareiviai. Maisto davinio komponentus ir vieniems, ir kitiems stengtasi pagal galimybes keisti, kad diena iš dienos nesikartotų tie patys patiekalai. Pietums visiems kareiviams paprastai patiekdavo kruopų, ryžių, žirnių, makaronų, pupelių, bulvių košès arba šiupinio. „Kadro“ dalies atstovams skirtą porciją dar praturtindavo 160-260 g mėsos, o „keičiamiesiems“ dažniausiai tekdavo pasitenkinti trupučiu riebalų.

„Keičiamosios sudèties“, kaip ir „kadro“, kareiviams buvo vedami karinio rengimo užsièmimai, vyko bendrojo lavinimo pamokos. Pastarųjų turinị ir tikslą aiškiai atspindi pavadinimai: „Drausmès statutas“, „Gamtos pažinimas“, „Žemdirbystë“, „Lietuva“, „Higiena“, „Lietuvių kalba“, „Istori-

31 Laikinai einančio Drausmès bataliono vado pareigas kpt. P. Saladžiaus $1923 \mathrm{~m}$. spalio 21 d. raportas II pèstininkų divizijos vadui // LCVA, f. 763, ap. 1, b. 80, 1. 118.

$321921 \mathrm{~m}$. Drausmès bataliono bendrieji dèsniai..., 1.1 .

33 Ten pat.

341922 m. vasario 3 d. Drausmės bataliono vado įsakymas // LCVA, f. 763, ap. 1, b. 46, 1. 87-88. 
ja“, „Karo istorija“, „Geografija“35.

Stengtasi, kad šios kategorijos kareiviai neturètų daug laisvo laiko ${ }^{36}$. Todèl „keičiamiesiems" vadovybė nuolat rasdavo įvairių darbų. Sukti galvos dèl to netekdavo: be kasdienių buitinių reikalų, bataliono teritorijoje nuolat vykdavo patalpų remontas, reikejjo apsirūpinti malkomis, prižiūrèti arklius ir t. t. Šalia kareivinių buvo įrengtos dirbtuvès. Be to, nuo $1922 \mathrm{~m}$. vidurio iki 1923 m. pradžios apie 200 Drausmès bataliono „keičiamosios sudèties kareivių talkino tiesiant geležinkelị ${ }^{37}$.

Darbas laikytas viena iš tinkamiausių auklèjimo priemonių. Auklèjimo ir drausminimo principus turejo reguliuoti Drausmès bataliono komitetas, kurị sudare pirmininkas (dalinio vadas), kuopų vadai, kapelionas. Posėdžiuose galejo dalyvauti ir gydytojas. Komitetas turejo teisę „keičiamiesiems“ kareiviams „už žinojimą tarnybos ir pavyzdingą elgimąsi“ sumažinti anksčiau skirtos bausmès Drausmès batalione trukmę net iki trečdalio ${ }^{38}$. Be to, ypač gerai užsirekomendavusieji galèjo būti išleidžiami be palydovo ị Varnių miestelị „tarnybos arba asmeniniais reikalais“. Dar daugiau - buvo net numatyta galimybė tokiems kariams švenčių proga suteikti keturiolikos dienų atostogas. „Keičiamosios sudèties“ kariai šventadieniais būdavo vedami ị pamaldas, pasivaikščioti, vasaros metu - prie vandens telkinių išsimaudyti. Tačiau laisvalaikiu jiems, skirtingai nei „kadro kareiviams“, kurie net rengdavo vakarones ir futbolo varžybas, neleista linksmintis. Tai buvo drausmès režimo dalis. Pažeidus jị arba bendrąją tvarką, grèsè papildomi nemalonumai.

„Drausmès bataliono bendruosiuose dėsniuose“ buvo nustatytos konkrečios bausmès už blogą elgesį. Oficialiai, idant nebūtų vienašališkai pikt-

\footnotetext{
351922 m. sausio 1 d. Drausmès bataliono vado iqsakymas Nr.1 // LCVA, f. 763, ap. 1, b. $46,1.1$.

36 Tai ypač akcentuota dar Drausmès bataliono pirmtakès - Atsargos kuopos vidaus tvarkos nuostatuose. Juose pabrèžta, kad „Atsargos kuopa yra darbštumo mokykla“, todèl „keičiamosios sudèties“ kareiviams „darbo valandų privalo būti ne mažiau 12 val. ị parą; rikiuotès [mokymams] - 3 val., gimnastika ir sportas - 1 val., bendro lavinimo pamokų - 3 val., amatams - 3 val., pamokų ruošimas - 2 val., valgiui ir poilsiui - 4 val., nakties poilsiui (miegui) - 8 val.“: Isakymas Lietuvos kariuomenei Nr. 343, 1920 gegužés 27 d., Kaunas, Rikiuotès skyrius.
}

37 Šalkauskas H., min. str., p. 386.

$381921 \mathrm{~m}$. Drausmès bataliono bendrieji dèsniai..., 1. 3 . 
naudžiaujama, jas skirti galejo tik Drausmès bataliono komitetas. Šios bausmès iš esmès buvo dviejų rūšių. Pirmoji „Bendruosiuose dėsniuose“ apibūdinta taip: „tinginiams - apsileidèliams miegas gali būti sumažinamas iki penkių valandų [per parą]. Atimtos miego valandos skiriamos ruošos ir ūkio darbams “39. Antroji bausmès rūšis - daboklè (nuo kelių dienų iki kelių ménesių $)^{40}$. Ir vieną, ir kitą vargu ar kas pavadintų „nerimtomis“, nedarančiomis poveikio. Tai buvo civilizuotų šalių kariuomenėse iprastos priemonės, nelaikomos brutalaus karinio muštro išraiška. Deja, to 1921-1922 m. Lietuvos kariuomenès Drausmès bataliono vadovybei atrodè per maža ir ji èmèsi „kūrybiškų eksperimentų“. Apie tai, kiek ir kaip tikrovè prasilenkè su reglamentais, - kitame skyriuje. O baigiant ši, reikètu pažymėti, kad tuo metu susikompromitavusios vadovybės pakeitimas oficialioms Drausmès bataliono vidaus tvarkos nuostatoms didesnès įtakos neturejjo, nors, žinoma, faktinė situacija pagerejjo. 1923 m., kaip ir iki tol, vyko standartiniai „keičiamosios sudèties“ kareivių mokymai, darbinis auklèjimas (kareivinių remontas, ūkiniai reikalai ir t. t.). Tačiau tais metais Drausmès batalionas vèl sušméžavo vieno rezonansinio įvykio fone. Lietuvos valdžia, likvidavusi belaisvių ir koncentracijos stovyklas, mané galinti šią netektį „kompensuoti“ pavesdama jai labai įsipykusius politinius veikejus „pagloboti“ Varniuose įsikūrusiam daliniui. Pirmuoju tokiu „Svečiu“, nepaisant jo atkaklių protestų ${ }^{41}$, tapo Kauno karo komendanto už beatodairišką Vyriausybès šmeižimą nubaustas buvęs pirmasis Lietuvos

\footnotetext{
39 Ten pat.

40 Atsargos kuopos vidaus tvarkos nuostatuose izoliavimo areštinëje (daboklëje) bausmè buvo gana smulkmeniškai reglamentuota. „Keičiamosios sudèties“ kareiviai galèjo būti baudžiami „žiauriu“ arba „mišriu“ areštu. Pirmuoju atveju būdavo skiriamas menkas ir skurdus maisto davinys: pusryčiams - beveik du šimtai gramų duonos (pusė svaro), pusė litro šilto virinto vandens ir mažytis gabalèlis cukraus; pietums - pusè litro sriubos ir beveik du šimtai gramų duonos. „Mišrų“ areštą sudarydavo dvi dienos „žiauraus“ ir viena diena paprasto arešto. „Žiauriu“ areštu kuopos vadas galejjo bausti iki 5 parų, puskarininkiai - tik 1-2 paroms. Kuopos teismas galèjo šią bausmę skirti net 12 parų. „Mišrus“ areštas galejo trukti triskart ilgiau. Žr.: Isakymas Lietuvos kariuomenei Nr. 343, 1920 m. gegužès 27 d., Kaunas, Rikiuotès skyrius.

411923 m. lapkričio pab. A. Voldemaro skundas gen. S. Žukauskui // Lietuvos mokslu akademijos bibliotekos Rankraščiu skyrius, f. 172, saug. vnt., 486, l. 1; A. Voldemaro 1923 m. lapkričio 4 d. skundo Kauno miesto tarybai nuorašas // Kauno apskrities archyvas, f. 219 , ap. 1, b. 286, 1. 27.
} 
Respublikos ministras pirmininkas prof. Augustinas Voldemaras. Nepavyko nustatyti, ar po to dar kas nors iš žymesnių civilių ten "paviešẻjo“, bet, panašu, kad A. Voldemarui ši atoki vieta opozicionieriams izoliuoti pasirode tikrai tinkama. Iškart po 1926 m. gruodžio 17-osios perversmo antrąkart èmęs vadovauti Ministrų Kabinetui, ambicingasis profesorius palaimino koncentracijos stovyklos buvusioje Drausmès bataliono teritorijoje steigimą ${ }^{42}$.

Pats batalionas, mažinant Lietuvos kariuomenę, dar 1924 m. pradžioje susitraukè iki kuopos ${ }^{43}$, o 1926 m. pavasarị ją nuspręsta perkelti ị Kauną (i šalia Aukštosios Panemunès esantị V fortą). $1928 \mathrm{~m}$. kuopa buvo integruota ị Karo kalejjimą ${ }^{44}$, ịsikūrusị VI forte.

Apibendrinat skyrių galima pažymèti, kad Drausmès kuopos (bataliono) raida XX a. trečiojo dešimtmečio pirmoje pusejje gerai atspindi pačius būdingiausius Lietuvos kariuomenès kūrimosi bruožus: bandymus kūrybiškai pritaikyti patirtị, igytą carinès Rusijos laikais, pastangas išsiversti naudojantis skurdžia materialine baze, nesibaigiančias struktūrines pertvarkas.

\section{SKANDALO PRIELAIDOS}

Pristačius bendrąą informaciją apie Drausmès bataliono kūrimąsi Varniuose 1921-1922 m., galima sutelkti demesị ir ị kur kas komplikuotesnes jo vidaus gyvenimo detales, išryškèjusias archyviniuose dokumentuose.

Pirmas rimtas signalas, kad atokiame šalies užkampyje dislokuotame specialiosios paskirties kariniame dalinyje vyksta kažkas neaiškaus ir negero, KAM pasiekė 1921 m. vèlyvą pavasarị. I Kauną buvo pranešta, kad

\footnotetext{
42 Plačiau apie 1927-1932 m. Varniuose veikusią koncentracijos stovyklą žr.: Kuodys M., min. veik.

43 Pagal 1923 m. pabaigoje patvirtintus Drausmès kuopos taikos meto etatus dalinyje turèjo būti 4 karininkai, 3 viršilos, 12 vyresniųjų puskarininkių, 15 jaunesniųjų puskarininkių, 12 grandinių ir 178 eiliniai. Žr.: 1923 m. gruodžio 1d. Drausmès kuopos taikos meto etatai // LCVA, f. 763, ap. 1, b. 103, 1. 1.
}

44 Stoliarovas A., min. str., p. 123. 
gegužès $10 \mathrm{~d}$. Varniuose, už Drausmès bataliono teritorijos ribų, sargybinis nušovė du pabėgti bandžiusius kareivius ${ }^{45}$. Suvokiant šio sudètingo laikotarpio kasdienybę, atrodytų, kad tokia žinia kariuomenės vadovybės neturèjo labai sukrèsti, nes pavienių kareivių mirčių šalyje išsibarsčiusiuose daliniuose dèl įvairių nelaimingų atsitikimų ar ūmių, nenustatytų ligų pasitaikydavo nuolat ir tai buvo laikoma natūraliu dalyku. Tačiau abstraktūs pirminiai ịvykio faktai atrodè itartini: du „keičiamosios sudeties“ kareiviai, lydimi ginkluotų sargybinių, ankstų gegužès rytą išèjo prie nelabai toli nuo dalinio pastatų esančio upelio žvejoti su tinklu; patikimo paaiškinimo, kas ten vèliau iš tiesų atsitiko, niekas nepateikè, tik tos žvejybos rezultatas neginčijamas - du kūnai su šautinèmis žaizdomis. Tokios aplinkybès neleido apsiriboti formalumais. Inicijuotą tyrimą koordinavo Kariuomenės teismo tardytojas ypatingoms byloms plk. Viktoras Engleris ${ }^{46}$. Jis per tarpininkus èmè organizuoti potencialių liudininkų apklausas ${ }^{47}$. Reikiama medžiaga per kelis ménesius buvo surinkta, išanalizuota ir įvertina. Nustatyta, kad sargybinis elgèsi pagal statutą - prieš šaudamas bėgančiuosius kelissyk garsiai perspejjo ir tik ịsitikinęs, kad reikalavimas ignoruojamas, paleido mirtinus šūvius. Dèl to Kariuomenès teismas 1921 m. rugpjūčio 29 d. posèdyje, „neradęs nusikaltimo sudèties“, bylą „numarino“48.

Nors tyrimas parode, kad kulkos ì „keičiamosios sudèties“ kareivius buvo paleistos teisètai, KAM èmé akivaizdžiai nepasitikèti Drausmès bataliono vadovybe. Varniuose vienas po kito pradejo lankytis ịvairaus rango tikrintojai. Pirmasis su tokia misija atvyko karininkas ypatingiems reikalams prie KAM plk. Vincas Grigaliūnas-Glovackis. Jis dalinyje praleido net tris savaites (1921 m. rugpjūčio 29-rugsèjo 18 d.) ir, kaip pats savo aštuonių lapų ataskaitos (vietoje kurios, jo paties tvirtinimu,

\footnotetext{
45 Drausmès bataliono vado 1921 m. gegužès 11 d. telefonogramos Nr. 55 Vietinès kariuomenès brigados vadui nuorašas // LCVA, f. 507, ap. 6, b. 1815, 1. 46.

46 Reikètų patikslinti, kad V. Engleriui Lietuvos kariuomenès pulkininko laipsnis buvo suteiktas tik 1926 m., iki tol leista oficialiai vadintis „rusų tarnybos pulkininku“. Žr.: Stoliarovas A., min. veik., p. 99-100.

47 Kariuomenès teismo tardytojo ypatingoms byloms plk. V. Englerio $1921 \mathrm{~m}$. birželio 13 d. raštas Biržų nuovados teismo tardytojui // LCVA, f. 507, ap. 6, b. 1816, l. 281.

48 Kariuomenès teismo tardytojo plk. V. Englerio $1922 \mathrm{~m}$. liepos 20 d. pažyma // LCVA, f. 507, ap. 6, b. 1816, 1. 273.
} 
esą reikètų surašyti „visą eilę tomų“) ${ }^{49}$ pradžioje pažymèjo, „batalionas tapo aprevizuotas ir prainspektuotas visais atžvilgiais, nuo pat savo gyvenimo pradžios“50. Didesnių priekaištų dèl materialinių dalykų Drausmès batalionui plk. Grigaliūnas-Glovackis nepareiškè. Kareivių išvaizda, nepaisant šiek tiek aptrintų uniformų, pasirodė gana gera, gyvenamųjų patalpų įrengimas - pakenčiamas, maitinimas - neblogas. Žinoma, formuluodamas išvadas, jis atsižvelge i apskritai skurdų to meto Lietuvos kariuomenès aprūpinimą. Pavarčius 1920-1921 m. KAM ịsakymus, kuriuose pateikti ịvairių dalinių apžiūrų protokolų fragmentai, galima rasti gerokai labiau šokiruojančių varganos kareivių buities pavyzdžių. Tačiau bendras ịspūdis, kurị pareigūnui paliko Varnių realybė, jo paties žodžiais tariant, buvo „sunkus“. Ataskaitos išvadose konstatuota, kad Varniuose susiklosčiusi situacija kompromituoja kariuomenę, teikia peno bolševikų propagandai, o tai esą gali „privesti prie katastrofos“ ${ }^{\text {51 }}$. Kaip vieną didžiausių problemų plk. Grigaliūnas-Glovackis ịvardijo kareivių siuntimo ì Drausmès batalioną be teismo sprendimo praktiką. Pareigūnas išsiaiškino, kad būta „daug neteisybių ir skriaudų, daromų kareiviams dalyse [daliniuose - M. K.] - už mažiausią menkniekị neištyrus dalyko siųsti drausmès dalin, didesnè dalis net nuteistų nežino savo kaltès ir ịkliuvę dèl tos ar kitos nelaimès ${ }^{\text {“52 }}$. Remdamasis tuo, KAM revizorius iškèlè prielaidą, kad pulkuose, iš kurių i Varnius be teismo atsiunčiama daugiausiai kareivių, karininkai abejingi savo pareigoms arba apskritai nesugeba auklèti šauktinių ir laikosi ydingos nuostatos, kad tai geriausiai atliks Drausmès batalionas. Tačiau ir pastarojo kadrai, pasak plk. Grigaliūno-Glovackio, tokiam darbui arba nepasiruošę, arba neturi reikiamų moralinių savybių. Ataskaitos autorius ryžosi net tokiai drastiškai išvadai: „Drausmès batalione netinkamas elgesys puskarininkių, netaktas karininkų priverčia juos

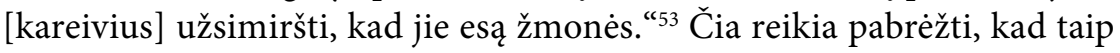
pareiške ne šiaip koks aukštais etiniais ir moraliniais standartais susirū-

\footnotetext{
49 Karininko ypatingiems reikalams prie KAM plk. Vinco Grigaliūno-Glovackio $1921 \mathrm{~m}$. spalio 1 d. raporto KAM nuorašas // LCVA, f. 507, ap. 6, b. 1816, 1. 53.

50 Ten pat, 1. 45.

51 Ten pat, 1. 53.

52 Ten pat.

53 Ten pat.
} 
pinęs KAM kanceliarijos idealistas, bet „kieta ranka“ - teisinių skrupulų nevaržomo „kazokų atamano“ elgesiu Nepriklausomybės kovų metu pagarsejęs karininkas ${ }^{54}$. Tiesa, jis sutiko, kad auklejant tikrai nusikaltusius kareivius prasminga naudoti „stipresnius“, nei oficialiai patvirtinti, metodus. Savo požiūrị jis argumentavo taip: „Šitame atvejy būtinas reikalas išdirbti drausmès batalionui taisykles, žinoma, čia negali būti normalios bausmès, sulig tik drausmès statuto, kadangi kitaip drausmès batalionas nustoja savo prasmès. “55 Tačiau kartu inspektorius pripažino, kad „iki išleidimui tokių instrukcijų bei normų, palaikymui drausmès [batalione] viršininkai vykdo savo sumanymus, kas yra panašaus ant savivalès ir [pa]kenčiama būti negali, idant išvengus traukimo žmonių [karinin-

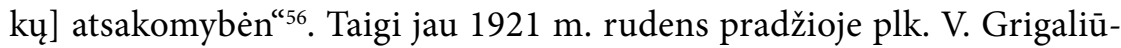
nas-Glovackis lankydamasis Varniuose, atrodo, sužinojo, už ką lygiai po metų buvo teisiamas Drausmès bataliono vadas. Tačiau KAM inspektorius neleistino kareivių kankinimo problemos savo ataskaitoje neakcentavo, labiau stengèsi pabrèžti žemą daugumos Drausmès bataliono karininkų ir puskarininkių kvalifikaciją (prastą karybos dalykų išmanymą), menką moralinị autoritetą. Pasak jo, dèl „inteligentiškų pajègų“ stygiaus joks rimtesnis kareivių švietimas ir auklejjimas esą neįmanomas. Tačiau ịdomiausia tai, kad iš prastai apibūdintos Drausmès bataliono karininku daugumos V. Grigaliūnas-Glovackis išskyrè dalinio vadą vyr. ltn. J. Nevroni, kuris, pulkininko nuomone, buvo gana kompetentingas, veiklus, stengèsi išnaudoti visas galimybes, kad tik palaikytų tvarką. Dèl to ataskaitoje net siūlyta jam pareikšti padèką ir suteikti kapitono laipsnį. Toks žingsnis - įrodinèjo V. Grigaliūnas-Glovackis - ne tik dar labiau motyvuotų vyr. ltn. Nevronị, bet ir padidintų jo autoritetą ${ }^{57}$. Iš tiesų Drausmès kuopoje buvo keli vyresnieji leitenantai, tad dèl amžiaus Nevronis (27 m.) nelabai galejo jaustis pranašesnis, pabrèžti savo, kaip vado, statusą, pavyzdžiui, prieš jau gerokai „pagyvenusị“ vyr. ltn. Joną Džiuvę (38 m).

\footnotetext{
54 Žr.: Jankauskas V., Vincas Grigaliūnas-Glovackis. Ilgai keiktas... // Nepriklausomos Lietuvos generolai, d. 1, Vilnius: Vilniaus dailès akademijos leidykla, 1998, p. 39-46.

55 Plk. Vinco Grigaliūno-Glovackio 1921 m. spalio 1 d. raporto KAM nuorašas, 1. 52.

56 Ten pat, 1. 52 .

57 Ten pat, 1. 53.
} 
KAM neatsižvelgè ì plk. V. Grigaliūno-Glovackio rekomendacijas ir Drausmès bataliono vado nesiskubino paaukštinti. Užtat dėmesys jo vadovaujamam daliniui nemažejo. Atrodo, kad tai paskatino vyr. ltn. J. Nevroni pavaldinius giežčiau kontroliuoti. Kaip jam tai sekėsi, sunku nustatyti, bet savo intencijas raštiškuose ịsakymuose batalionui jis stengèsi demonstratyviai pabrěžti. Matyt, ruošèsi kitam patikrinimui ir norejjo, kad dokumentai bylotų apie jo principingumą. Smarkokai pavaldiniams pylos vyr. ltn. J. Nevronis davė $1922 \mathrm{~m}$. sausio $1 \mathrm{~d}$. Iš raštiškame įsakyme batalionui esančių užuominų galima spėti, kad didžiąsias žiemos šventes daugelis karininkų ir puskarininkių praleido tikrai „smagiai“. İsakyme pažymėta, kad „ypatingai iš pusès karininkų begalinis girtuokliavimas ir retas išsiblaivejjimas privedè prie tokių apsireiškimų, už kuriuos kalti traukiami atsakomybèn teismo keliu ir baudžiami aukščiausiu laipsniu“" ${ }^{\text {". }}$. Todèl bataliono vadas uždraudè pavaldiniams ,vaikštinèti ị miestą girtuokliavimo tikslais, t. y. lankyti Varnius, miesto girtuokliavimo įstaigas", ir pažadejo „visus neblaivius sutiktus gatveje talpinti į atitinkamas dabokles“. Savo perspejjimus ir nurodymus vyr. ltn. J. Nevronis baigė pranašišku naujamečiu linkejjimu: „Linkiu bataliono kariškiams išvengti šiuose metuose panašių prasižengimų, nes mūsų kariuomenẻ kasdiena tobulinasi ir kasdiena didinasi iš jos reikalavimai“. Iš tiesų KAM dejjo daug pastangų, kad išaiškintų ir išspręstų kariuomenès vidaus problemas, kol jos neiškilo ị viešumą. $1922 \mathrm{~m}$. pirmoje pusejje i̇ Varnius vèl buvo atsiųsti inspektoriai - reikejo nuodugniau ịvertinti ankstesnès revizijos ataskaitoje nurodytas negeroves ir imtis priemonių joms pašalinti. Juo giliau buvo kapstomasi, tuo labiau Drausmès bataliono vadas „klimpo“ i jam nepalankių ịtarimų liūną.

Remiantis tam tikromis kontekstinèmis užuominomis archyviniuose dokumentuose, galima numanyti, jog 1922 m. sausio viduryje Varniuose lankèsi Kariuomenès teismo sistemos atstovas. Tiksliai asmens ir pareigu nepavyko nustatyti, bet, atrodo, tai buvo kažkoks valstybės gynejo ( $\mathrm{t}$. $\mathrm{y}$. prokuroro) padejejejas ar igaliotinis. Tačiau svarbiausia šiuo atveju yra tai, kad šis vizitatorius Drausmès batalione sulaukè žodinių skundų ar aptakių užuominų, jog dalinyje su kareiviais elgiamasi žiauriai - naudojamos sveikatą žalojančios fizinio poveikio priemonès. Ši informacija netrukus

58 Drausmès batalionui įsakymas Nr. 2, 1922 m. sausio 2 d. // LCVA, f. 763, ap. 1, b. 46, 1. 3 . 
pasieke krašto apsaugos ministrą prof. Joną Šimkų. Panašias su karininkų ir karių savivale susijusias problemas jam tuo metu tekdavo spręsti nuolat ${ }^{59}$. Ministras nedelsdamas davè nurodymą Vietinès kariuomenès brigados vadui mjr. A. Merkiui išsiaiškinti situaciją. Šis tuo užsiimti pavedė žemesniajai savo vadovaujamos struktūros grandžiai - Telšių karo komendantui mjr. Steponui Rusteikai ${ }^{60}$. Issakymą nedelsiant imtasi vykdyti. Varniuose kpt. S. Rusteika praleido dvi dienas - sausio 22-ąją ir 23-iąją. Raporte viršininkui jis pažymejjo, kad apklause dalinio gydytoją, karininkus, ,apvaikščiojo visas kareivines, dabokles ir abelnai [apskritai - M. K.] visus pašalius“, bet nieko neišgirdo ir niekur nematė „nė vieno apmušto žmogaus“61. Apie smurtą teiravosi ir „areštuotų“ (t. y. areštinejje sẻdejjusių) kareivių, tačiau niekas jokių pretenzijų nepareiškè. Be to, pats bataliono vadas tikrintojui asmeniškai davė „garbès žodį", kad niekas kareivių nemušè. Savo vizitą mjr. S. Rusteika baigè profilaktiniu pokalbiu. Sušaukęs visus bataliono karininkus, jis griežtai i̇spejo, kad už „kožną sauvališką pasielgimą prisieis jiems nešti sunkią atsakomybę “62.

Taigi Telšių karo komendantui nieko nepavyko išsiaiškinti. Krašto apsaugos ministerijos tai netenkino - įtarimai neatrode patikimai išsklaidyti. Todèl nuspręsta viso šio reikalo nepalikti iki galo neištirto, toliau ieškoti neteisètų veiksmų ịrodymų. Panašiu metu tokią užduotị gavo specialus KAM inspektorius ir Generalinio štabo Žvalgybos skyrius ${ }^{63}$. Pastarasis, atrodo, dirbo neoficialiai, savo ịprastais metodais, su kitomis suinteresuotomis struktūromis per daug nebendraudamas, nes raštiškų ataskaitų, išskyrus kai kurių tiriamų faktų liudininkų parodymus, nepavyko rasti. Galbūt jos neišliko arba „pasislèpe““ gana painiai suarchyvuotoje to laikotarpio Žvalgybos skyriaus veiklos dokumentacijoje. Šiaip ar taip, šios niūrios Drausmès bataliono istorijos atomazgai didžiausią ịtaką turèjo karininko

\footnotetext{
59 Blažytė-Baužienė D., Profesorius Jonas Šimkus // Lietuvos krašto apsaugos ministrai ir kariuomenés vadai, t. 2, Vilnius: Krašto apsaugos ministerija, Vytauto Didžiojo karo muziejus, 2008, p. 79.

60 Vietinès kariuomenès brigados vado 1922 m. sausio mèn. telefonograma Telšių karo komendantui // LCVA, f. 507, ap. 6, b. 1816, 1. 242.

61 Telšių karo komendanto mjr. S. Rusteikos $1922 \mathrm{~m}$. sausio 24 d. raportas Vietinès kariuomenès brigados vadui // $L C V A$, f. 507, ap. 6, b. 1816, 1. 240.

62 Ten pat.

${ }^{63}$ Budrys J., min. veik., p. 182.
} 
ypatingiesiems reikalams prie krašto apsaugos ministro mjr. Jurgio Bylos atliktas tyrimas. Jis suteikè galimybę oficialiai pareikšti kaltinimus Drausmès bataliono vadui. Prasminga pridurti, kad minètas inspektorius pasižymejjo aukšta kompetencija, nepriekaištinga reputacija ir polinkiu ieškoti tiesos, nepaisant, kokia nemaloni ji galètų pasirodyti ar kiek pastangų tos paieškos pareikalautų ${ }^{64}$.

1922 m. balandžio 3 d. mjr. J. Byla gavo specialų raštišką savo tiesioginio viršininko krašto apsaugos ministro Balio Sližio issakymą. Ypatingụjų reikalų karininkui nurodyta nedelsiant vykti ị Varnius ir patikrinti Kariuomenès teismo valstybès gynejjo (prokuroro) pateiktą informaciją "apie terorizavimą tame batalione nusikaltusių kareivių “65. Šiame įsakyme bene pirmą kartą buvo sukonkretinta, kaip reikètų suprasti žodị „terorizavimas“, - turètas omenyje mušimas, laikymas susirietusių vyrų ankštuose narvuose. Dokumentas taip pat suteikè teisę mjr. J. Bylai reikalauti iš kariuomenès dalinių vadų, karo komendantų, vietos savivaldybių visokeriopos pagalbos, būtinos „tarnybos pareigas einant“.

Ypatingųjų reikalų karininkas Varniuose praleido savaitę (balandžio 6-12 d.). Per tą laiką jis ne tik nuodugniai išstudijavo bataliono dokumentus, bet ir atliko 21 kvotą - apklausè su tiriamais faktais vienaip ar kitaip galimai susijusius kareivius ir karininkus. Surinktą medžiagą mjr. J. Byla apibendrino išvadose. Visas jas iš eilès pristatyti ir komentuoti nelabai verta, nes lemiamą reikšmę turejo tik kai kurios iš jų. Inspektorius surinko pakankamai ịrodymų, kad Drausmès batalione nusikaltę „keičiamosios sudèties kareiviai“ buvo ne tik spontaniškai apstumdomi ir apkumščiuojami - jiems dažnai rengtos ir savotiškos egzekucijos. Kvotų metu paaiškèjo, kad „rykštès tame batalione buvo vartojamos ligi $1921 \mathrm{~m}$. gegužès ar birželio mėnesio“66. Inspektoriui pavyko rasti protokolą, kuriame nurodyta,

64 1920-1921 m. krašto apsaugos ministro pareigas ejęs plk. Konstantinas Žukas savo tuometị padejjèją J. Bylą po daugelio metų emigracijoje rašytuose memuaruose apibūdino itin prielankiai: „Iš jo [J. Bylos - M. K.] turèjau ypač daug naudos. Tai buvo aukštos moralès, šalto ir sveiko proto žmogus. Socialdemokratas, karštas patriotas, idealistas, humanistas. Vèliau kartu dirbant jis dažnai mane veikè taip kaip šaltas kompresas karščiuojantị Žmogų. “ Žr.: Žukas K., Žvilgsnis ị praeitį, antras leid., Vilnius: Mintis, 1992, p. 185.

65 Krašto apsaugos ministro B. Sližio $1922 \mathrm{~m}$. balandžio $3 \mathrm{~d}$. slaptas skubus ịsakymas mjr. J. Bylai // LCVA, f. 507, ap. 6, b. 1815, 1. 5.

${ }_{66}$ Mjr. J. Bylos 1922 m. balandžio 25 d. raportas KAM // LCVA, f. 507, ap. 6, b. 1815, 1. 7. 
kad tų pačių metų sausio mėnesị rykštėmis (nuo 10 iki 100 kirčių) buvo nubausta 16 kareivių. Tai neturètų labai šokiruoti - carinès Rusijos kariuomenès drausmès daliniuose tokios baudžiavos laikus primenančios fizinès bausmès buvo ịteisintos ir praktikuotos net Pirmojo pasaulinio karo metais ${ }^{67}$. Ivairiose besikuriančios Lietuvos kariuomenès srityse, gana plačiai remiantis „rusiška patirtimi“, matyt, bandyta pratęsti ir šią demokratinei valstybei tikrai garbès nedarančią „tradiciją“. Lietuvos kariuomenès vadovybé tokių priemonių niekada nebuvo sankcionavusi - jas Varniuose dislokuoto dalinio karininkai nusprende taikyti savo nuožiūra - „pažodžiui“ vadovaudamiesi rusiškais kariniais įstatymais. Tai savo raporte pabrěžè ir mjr. J. Byla, primindamas, kad fizines bausmes draude ir tuo metu galiojusi laikinoji Lietuvos Valstybès Konstitucija. Tačiau raporte užfiksuotas „rykščių epizodas“ - ne vienintelis ir ne pats rimčiausias žiauraus, neteisèto elgesio pavyzdys, nes, kaip pažymėjo inspektorius, „mušimas kareivių kumščia, nagaika [trumpas, iš odos atraižų supintas raitelio rimbas arba vytinis - M. K.], lazda, diržas batalione [buvo] vartojamas visą laiką ir net laike mano apsilankymo batalione ${ }^{\text {“68 }}$. Šis smurtavimas baigdavosi ịvairiais kūno sužalojimais, tokiais kaip „ausų apkurtimas“, „kraujo išsiliejimas po oda“, „smegenų uždegimas“. Mjr. J. Byla taip pat nustatè, kad skundai dèl kareivių kankinimo narvuose - ne prasimanymas. Raporte jis nurodè, kad prie bataliono daboklès buvo įrengtos keturios iš lentų sukaltos dèžès su tarpais - vadinamieji narvai (dokumentuose dažniausiai figūruoja rusiškas žodis „kletka“), kuriuose vidutinio ūgio vyras negalejo nei atsistoti, nei apsisukti. Tokia bausmè trukdavo net dvi tris paras. Be to, nustatyta, kad nusikaltę kareiviai už nugaros surištomis rankomis kelioms valandoms buvo kabinami ant vieno iš pastatų rūsio sienoje ịtaisytų kablių. Tai buvo tikras kankinimas: taip kabančio žmogaus kūno svoris skausmingai lauždavo sąnarius, virvės iki kraujo ịsirèždavo ị riešus. Ir tai dar ne viskas. Ypatingųjų reikalų karininkas sužinojo ir apie kitus, nors ir ne tiek sveika-

\footnotetext{
67 Tai paliudyta ir Rusijos kariuomenès artilerijos dalinyje Pirmojo pasaulinio karo metais tarnavusio lietuvio iš Pakaunès Jurgio Jekelaičio atsiminimuose. Žr.: Jekelaitis J., Jeigu kas nors skaitys. Atsiminimai, Kaunas: Spindulys 1996, p. 100-103. Beje, būsimasis Lietuvos kariuomenès Drausmès bataliono vadas Jurgis Nevronis tada taip pat tarnavo puskarininkiu artilerijoje.
}

68 Mjr. J. Bylos 1922 m. balandžio 25 d. raportas KAM, 1. 7. 
tai pavojingus, kareivių „terorizavimo“ būdus: vertimą ịsikandus ị dantis metalinị katiliuką šokčioti atsitūpus (t. y. lyg ir vaikščiojimas „žąsele“) ${ }^{69}$, daug sykių gultis ị pusnị ir stotis (žiemos metu) ir kitus panašius dèl „pramogos“ sugalvotus pasityčiojimus. Kai kurias išvardytas smurtavimo ir neteisèto elgesio formas patvirtino ir Lietuvos kariuomenès kontržvalgybos atstovų apklausti civiliai asmenys, gyvenę šalia bataliono arba kartkartėmis darbo reikalais patekdavę $\mathfrak{i}$ dalinio teritoriją ${ }^{70}$. Visų šių savivalès ir smurto apraiškų priežastimi mjr. J. Byla laike „netikusį bataliono karininkų sąstatą" - menkos kompetencijos, nemotyvuotą, nuolat girtuokliaujantị ir kortuojantị. Jis, priešingai nei prieš pusmetị situaciją Varniuose tyręs plk. V. Grigaliūnas-Glovackis, visai nebandè užtarti Drausmès bataliono vado J. Nevronio ir visą kaltę suversti ji supusiai aplinkai. 11-oji raporto išvada labai kategoriška: „Bataliono vadas vyr. ltn. Nevronis neturi né amžiaus prityrimo, nè tarnystès stažo ir svarbiausiai jokio supratimo apie auklejimą ir pataisymą nubaustų kareivių. Visi jo gabumai apsireiškia vienoj srity, būtent terorizavime esančių jo žinioj kareivių. "71 Dèl to inspektorius rekomendavo bataliono vadą nedelsiant pašalinti iš posto ir vietoj jo paskirti koki „rimtą karininką, turintị šiek tiek pedagoginių gabumų“72. I naujus dalinius iš Varnių taip pat esą reikètų perkelti ir kitus „netikusius“ karininkus. Beje, vyr. ltn. H. Šalkauskas, 1928 m. spaudoje paskelbęs trumpą, gražų straipsni apie Drausmès bataliono kasdienybę, raporte taip pat nebuvo apibūdintas labai teigiamai ${ }^{73}$. Reikia pažymèti, kad jis ${ }^{74}$, kaip

691922 m. Kariuomenès teismo valstybès gynëjui kpt. Karoliui Žalkauskui mjr. J. Byla plačiau paaiškino šios bausmès taikymo aplinkybes: „Jeigu viršilos pastebi pas einančius pasiimti kareivius nešvarų katiliuką, tai liepia jiems įsikandus katiliuką šokinèti kaip varlèms prie katilo.“ Žr.: Mjr. J. Bylos 1922 m. balandžio 30 d. parodymų Kariuomenès teismo valstybès gynejjui protokolas // LCVA, f. 507, ap. 7, b. 550, 1. 3.

701922 m. KAM Generalinio štabo Žvalgybos skyriaus pažyma // LCVA, f. 10, ap. 1, b. $124,1.57-58$.

71 Mjr. J. Bylos 1922 m. balandžio 25 d. raportas KAM, 1. 8.

72 Ten pat.

73 Tačiau kitoje 1922 m. kpt. Prano Saladžiaus pasirašytoje charakteristikoje vyr. ltn. H. Šalkauskas buvo ịvertintas labai palankiai: „Drausmingas, auklejja ir mokina kareivius [tinkamai], rodo iniciatyvos. Tarnybai pasiaukoja. <...> Karininkas drausmingas, inteligentiškas, sąžiningas. “Žr.: H. Šalkausko 1922 m. atestacijos lapas // LCVA, f. 763 , ap. 1, b. $80,1.4$.

74 Vyr. ltn. H. Šalkauskas teigė nematęs nei jokio „keičiamosios sudèties“ kareivių mu- 
ir dauguma kitų Drausmės bataliono karininkų, mjr. J. Bylai juos apklausiant, laikèsi aiškiai gynybinès taktikos: kalbejjo mažai, glaustai, smurto ir patyčių sakèsi nematęs arba apibūdino šiuos atvejus kaip pavienius, iš dalies pateisinamus, neturejusius jokių rimtesnių padarinių kareivių sveikatai ir pan. ${ }^{75}$ Vis dèlto panašios interpretacijos inspektoriaus neįtikino - jis pateike tikrai griežtas išvadas. Kariuomenès teismo valstybės gynejui to pakako, kad pradètų ikiteisminị tyrimą, būtiną kaltinamajam aktui parengti. Sykiu tai ženklino pirmąji - „paslaptingiausią“ - kontroversiškos Drausmės bataliono Varniuose istorijos etapą. Jis, jei KAM nebūtų principingai reagavusi i nerimą keliančias žinias ir inicijavusi kelių nuodugnių patikrinimų, galèjo užsitęsti kur kas ilgiau ir virsti nemenku skandalu, kuris labai būtų pakenkęs Lietuvos kariuomenès ịvaizdžiui visuomenèje. Visos prielaidos tam buvo.

\section{BYLOS BAIGTIS IR KALTINAMOJO LIKIMAS}

Po ypatingųjų reikalų karininko mjr. J. Bylos apsilankymo Varniuose 1922 m. balandžio pradžioje atliktos revizijos ir kvotų situacija Drausmès batalione krašto apsaugos ministrui B. Sližiui tapo aiškesnè. Reikejjo nedelsiant spręsti problemą. Kariuomenès teismo valstybės gynėjas pradejo ikiteisminị tyrimą. Šis skyrius - apie jo baigtị ir pagrindinio kaltinamojo tolesnị likimą.

Oficialaus kaltinimo parengimas, net ir dirbant gana skubiai, turè-

šimo, nei tupinejjimo su katiliukais dantyse. Pripažino tik bausmès narve egzistavimą. Vyr. ltn. H. Šalkausko 1922 m. balandžio 11 d. parodymai mjr. J. Bylai // LCVA, f. 507, ap. 6, b. 1815, 1. 24.

75 Antai ltn. Jonas Džiuvė aiškino, kad be rykščių su kai kuriais kareiviais nepavykdavę susitvarkyti: esą „tik pavartojus bizūną" vienas nepataisomas vagišius pasakè, kur pardavẻ aštuonias iš bataliono kareivinių nugvelbtas antklodes. J. Džiuvès tvirtinimu, kareivių vertimas tūpčioti ịsikandus katiliuką buvo viso labo „gimnastika“. Žr.: Ltn. J. Džiuvès 1922 m. balandžio 11 d. parodymai mjr. J. Bylai // Ten pat, 1. 30. Šiam karininkui, kaip ir kai kuriems kitiems aktyviausiems tokios „gimnastikos“ rūšies propaguotojams, tai galiausiai „atsirūgo“ - prastai ịvertintas per atestaciją, $1923 \mathrm{~m}$. pavasarị jis buvo atleistas iš kariuomenès. Žr.: Lietuvos kariuomenès karininkai 1918-1953, t. 3, p. 97. 
jo užtrukti mažiausiai mėnesi, tačiau Varniuose per tą laikotarpi viskas likti po senovei nebegalejo. Iš pradžių imtasi švelnių kardomųjų priemonių - Drausmès bataliono vadas buvo laikinai nušalintas nuo pareigų, ji trumpam pakeitè mjr. Jonas Statkevičius. Be to, krašto apsaugos ministras įsakè Vietinès kariuomenès brigados vadui užtikrinti, kad „kūno bausmès“, būtent „rykštès“, kaip prieštaraujančios „Laikinosios Konstitucijos dèsniams“ dalinyje daugiau nebūtų praktikuojamos ${ }^{76}$. Tačiau šie nurodymai ir formalus vado nušalinimas tuo metu nepadejo iš esmès pakeisti psichologinès atmosferos Varniuose dislokuotame dalinyje. Gegužès viduryje Vietinès kariuomenès brigados vadą pasiekè žinios, kad „nekurie karininkai Drausmès bataliono, išvykus mjr. Bylai, kuris darė batalione tardymą, pradejjo tardyti visus kareivius, kurie tik buvo šaukiami pas [tyrèją], spèka [jèga - M. K.] vertè juos išsipasakoti, ką [jam] sakë“77. Beveik tuo pat metu mjr. J. Byla informavo Kariuomenės teismo tardytoją ypatingai svarbioms byloms plk. Viktorą Englerị, jog vizito Varniuose metu gavo anoniminị pranešimą, kuriame ịrodinėta, kad prieš metus du per žvejybą nušauti Drausmès bataliono kareiviai žuvo dèl kitų priežasčių, nei oficialiai nustatyta. Esą jie visai nebandẻ bėgti - sargybinis įvykdė šaltakraujišką egzekuciją paliepus ịtūžusiam vyr. ltn. Nevroniui, nes atsisakè su drabužiais bristi ì šaltą vandenị statyti tinklo ${ }^{78}$. Beje, tarp Varnių gyventojų tuo metu gana plačiai sklande kalbos, jog kareiviai buvo nužudyti dar ir dẻl to, kad galejjo žinoti daug pavojingų paslapčių. Sąmokslo teorijai gimti padejo skubotos žuvusiųjų laidotuvès ir apskritai įtartinas bataliono vadovybès elgesys tomis dienomis ${ }^{79}$. Tai buvo ne vienintelis atvejis, kai vyr. ltn. J. Nevroniui bandyta „prikabinti“ kaltę dèl žmogžudystès. Kariuomenès teismo tardytojas turèjo iš neaiškių šaltinių gautos informacijos, kad buvo dar bent vienas oficialiai pateisintas susidorojimas su eiliniu kareiviu. Tiksliau, pastarasis mirẻ nuo smegenų uždegimo vežamas iš Varnių ì Karo ligoninę Kaune.

\footnotetext{
76 Krašto apsaugos ministro B. Sližio $1922 \mathrm{~m}$. gegužès $10 \mathrm{~d}$. slaptas įsakymas Vietinès kariuomenès brigadai // LCVA, f. 507, ap. 6, b. 1815, 1. 12.

77 Vietinès kariuomenès brigados vado mjr. A. Merkio 1922 m. gegužès 17 d. ịsakymas e. p. Drausmès bataliono vadui mjr. Statkevičiui // LCVA, f. 507, ap. 6, b. 1816, 1. 1.

78 Slaptas skubus 1922 m. gegužès 16 d. mjr. J. Bylos pranešimas Kariuomenès teismo ypatingai svarbių bylų tardytojui plk. V. Engleriui // LCVA, f. 507, ap. 6, b. 1815, 1. 45.

791922 m. KAM Generalinio štabo Žvalgybos skyriaus pažyma // LCVA, f. 10, ap. 1, b. $124,1.57-58$.
} 
Ligos priežastis esą galèjęs būti nuolatinis mušimas ir jo sukeltos galvos traumos ${ }^{80}$. Pažymėtina, kad prieš kareivị smurtavo tas pats puskarininkis, kuris nušovė du anksčiau minètus bèglius. Po mènesio Kariuomenès teismą pasieke dar vienas dokumentas, savotiškai papildantis tuos kažkieno „ne protokolui“" pateiktus kaltinimus. Tai buvo vieno nuteisto dezertyro iš Drausmès bataliono malonès prašymo Lietuvos Respublikos Prezidentui nuorašas ${ }^{81}$. Laiške kareivis teisinosi iš dalinio pabėgęs dèl nuolatinio nepakeliamo smurto - bijodamas, kad anksčiau ar vèliau jam viskas baigsis taip pat kaip tam tarnybos draugui, kuris po galvos sumušimo susirgo ir mirè.

Kai Kariuomenès teismą pasiekè visos tos, kad ir nepatvirtintos, žinios apie galimai tyčinius kareivių nužudymus ir Drausmès bataliono karininkų bandymus įbauginti potencialius liudininkus, nuspręsta pagrindiniam ịtariamajam - dalinio vadui - pritaikyti griežtesnę kardomąją priemonę areštą. Gegužès 18 d. vyr. ltn. J. Nevronis buvo suimtas ir išvežtas ị Karo kalëjimą Kaune ${ }^{82}$. Dar prieš mènesị Vietinès kariuomenès brigados vadui mjr. A. Merkiui jis skundèsi tapęs pavaldinių šmeižikiško sąmokslo auka. Tada raporte aiškino, kad „tardymas majoro Bylos ịvedè batalione demagogiją ir baisiausius santykius tarpe karininkų, kurie, sumaišę savo asmeniškus dalykus su tarnyba", bando visą kaltę suversti dalinio vadui, kad juo nusikratytų ${ }^{83}$. Pagrindiniai intrigantai esą buvo kpt. Aleksejus Tiška (kitur dokumentuose - Tiško), ltn. Petras Jurgelevičius, ltn. Juozas Kaironis ir bataliono gydytojas Mečislovas Norkus ${ }^{84}$. Skaitant pastarojo parodymus,

${ }^{80}$ Kariuomenès teismo tardytojo ypatingoms byloms $1922 \mathrm{~m}$. gegužès $12 \mathrm{~d}$. nutarimo Nr. 3 nuorašas // LCVA, f. 507, ap. 6, b. 1815, 1. 71 .

81 Eil. Povilo Jandalo 1922 m. birželio 17 d. prašymo Lietuvos Respublikos Prezidentui nuorašas // LCVA, f. 507, ap. 6, b. 1816, 1. 262.

${ }^{82}$ Vyr. ltn. J. Nevronio 1922 m. rugpjūčio 6 d. pareiškimas Kariuomenès teismo pirmininkui // LCVA, f. 507, ap. 6, b. 1816, 1. 6.

${ }^{83}$ Vyr. ltn. J. Nevronio $1922 \mathrm{~m}$. balandžio $13 \mathrm{~d}$. raporto Vietinès kariuomenès brigados vadui nuorašas // LCVA, f. 507, ap. 6, b. 1815, 1. 76.

84 Dauguma minètų karininkų vyr. ltn. J. Nevronis Vietinès kariuomenès brigados vadui skundèsi dar iki mjr. J. Bylos inspekcijos. Štai ką jis pažymejjo viename iš savo raportụ 1922 m. pradžioje: „Iš prisiųstų karininkų penki batalionui netinkami. Kapitonas Tiška kaipo karininkas neblogas, bet jokio darbo atlikti negali. Leitenantas Jurgelevičius [dèl] savo vaikiškumo negali eiti pareigų karininko batalione: einant komendanto pareigas pavelija [leidžia - M. K.] sau sukruvinti [tvoti ị nosị - M. K.] vieną pilietị, atvežusị batalionan malkas. Kapitonas Alfonsas Ramašauskas per begalinị girtuokliavimą užsikrètė 
duotus mjr. J. Bylai, krinta ị akis jų „atvirumas“ - pripažistama, kad „keičiamosios sudèties“ kareiviai dažnai buvo mušami ir patirdavo gana sunkių sužalojimų ${ }^{85}$. Dauguma karininkų per apklausas, kaip anksčiau minèta, akivaizdžiai stengèsi dalini kompromituojančius faktus paneigti arba su-

sifelisu [sifiliu - M. K] ir randasi II atskiram lazarete [karo ligoninèje]. Kaipo karininkas žemina vardą, jokio jo [pasitaisymo] nesimato, nežiūrint ant dedamų pabaudų. Leitenantas Kaironis didelis apsileidèlis ir kaipo matyti tinginys - ant pabaudu atidos nekreipia, pareigų karininko batalione atlikti negali.“ Žr.: Drausmés bataliono vado vyr. ltn. J. Nevronio $1922 \mathrm{~m}$. vasario $10 \mathrm{~d}$. slapto raporto Vietinès kariuomenès brigados vadui nuorašas // LCVA, f. 507, ap. 6, b. 1813, 1. 226. Šiomis J. Nevronio pateiktomis jo tuomečių pavaldinių charakteristikomis galima kliautis tik iš dalies, nes bendriausi šių asmenų biografijų faktai galètų pagrịsti ir kiek kitokius vertinimus. Daugiausia neaiškių dèmių, atrodo, turèjo tik dviejų paminètų Drausmès bataliono kapitonų reputacija. A. Tiška išties buvo narsus karys - Pirmojo pasaulinio karo metais patyręs kelis sužeidimus, vokiečiu nelaisvę, gavęs ne vieną apdovanojimą (Šv. Anos 4-ojo laipsnio ordiną, Šv. Georgijaus (Jurgio) 3-iojo ir 4-ojo laipsnio kryžius, Šv. Georgijaus (Jurgio) 4-ojo laipsnio medalị), bet Lietuvos kariuomenèje nelabai sugebejjo pritapti, neišmoko lietuvių kalbos. Dèl šios priežasties jis $1922 \mathrm{~m}$. pabaigoje buvo pripažintas netinkamu tęsti tarnybą. Suprantama, kad skandalinga Drausmès bataliono istorija tokiai karininko karjeros baigčiai taip pat turèjo reikšmès. Apie A. Tiško žr.: Lietuvos kariuomenés karininkai 1918-1953, t. 8, p. 51. Kpt. A. Ramašauskas taip pat ilgiau kariuomenèje neužsibuvo - 1923 m. pabaigoje pasiprašė išleidžiamas ị atsargą. Žr.: Ten pat, t. 6, p. 223. Kiek kitokia buvo ltn. J. Kaironio (g. 1894) ir ltn. P. Jurgelevičiaus (g. 1901) situacija. Juos J. Nevronis apibūdino kaip nesubrendusius, perdèm ūmius, neatsakingus. Tai gali būti ir grynai asmeninio priešiškumo išraiška. Palankiau, geranoriškiau žiūrint, tokias savybes įmanoma pavadinti ir visai kitaip - jaunatvišku idealistiniu maksimalizmu ar gal kiek infantiliu principingumu. Neatmestina, jog dèl to tarp šių dviejų karininkų ir dalinio vado atsirado trintis ar net konfliktiški santykiai - pirmieji nenorejo taikstytis su praktikuojamomis negatyviomis caro armijos tradicijomis, oportunizmu. Daugiausia pagrindo tokiai prielaidai suteikia išskirtinè P. Jurgelevičiaus-Jurgèlos asmenybė. Gimęs JAV, kur tėvai laikinai uždarbiavo, Pirmojo pasaulinio karo metais mokęsis lietuviškoje i Voronežą perkeltoje gimnazijoje, kaip asmenybė susiformavęs veikiamas ten tvyrojusios patriotinès dvasios, jis liko jai ištikimas visą gyvenimą: pasižymėjo Nepriklausomybės kovose, aktyviai dalyvavo visuomeninejje veikloje, labai daug nuveikè spaudos baruose ne tik Lietuvoje, bet ir $1931 \mathrm{~m}$. išvykęs ị JAV (ten mire 1992 m.). Žr.: Lietuvos kariuomenés karininkai 1918-1953, t. 4, p. 111. Ltn. J. Kaironio biografijoje yra įrašyti dramatiškiausi kovų su lenkais epizodai, vieno kurio metu jis buvo sunkiai sužeistas. Žr.: Ten pat, t. 4, p. 130. Gal šių dviejų jaunesniųjų karininkų nepasitikejjimą ir antipatiją stiprino ir tai, kad jų viršininkui J. Nevroniui tiesiogiai neteko dalyvauti Nepriklausomybès kovose.

${ }^{85}$ M. Norkaus 1922 m. balandžio 11 d. parodymai mjr. J. Bylai // LCVA, f. 507, ap. 6, b. $1815,1.25-26$. 
švelninti, o gydytojas $M$. Norkus elgèsi priešingai - demonstravo norą padèti tyrimui ir pats faktiškai parašè kaltinimui teisme patogias medicinos ekspertizès išvadas. Tačiau daugiausia pagiežos vyr. ltn. J. Nevronis liejo ne jo, o kpt. A. Tiškos adresu. Kitame savo raporte Vietinès kariuomenès brigados vadui jis apibūdino A.Tišką kaip nuolat girtaujantị, vengiantị atlikti pareigas, rodantị blogą pavyzdị kareiviams ${ }^{86}$. Šie skundai - tai ne vien desperatiškos vyr. ltn. J. Nevronio pastangos apsiginti. Tikètina, kad juose būta tiesos: kai kurie pavaldiniai galèjo sąmoningai kenkti vadui, todèl kūrè tendencingas istorijas apie nesenus liūdnai pasibaigusius ịvykius.

Dèl visų šių iškilusių naujų ịtarimų ir poreikio patikslinti anksčiau gautus duomenis gegužès $31 \mathrm{~d}$. plk. V. Engleris išvyko ị Varnius ${ }^{87}$. Iki birželio $8 \mathrm{~d}$. jis aiškinosi situaciją, atliko papildomas ịvairių liudininkų apklausas. Kariuomenès teismo atstovą pirmiausia domino Drausmès bataliono vadui inkriminuojami dalykai, o viso dalinio veiklos rezultatus beveik tuo pačiu metu iš naujo ịvertinti pabande Vietinès kariuomenès brigados vadas mjr. A. Merkys. Birželio 24 d. jis išsiuntė aplinkraštị visų pulkų štabams, teiraudamasis grị̌usių iš šios perauklẻjimo vietos kareivių charakteristikų. Pažymètina, jog dauguma atsiliepimų buvo labai palankūs vyr. ltn. J. Nevroniui. Kai kuriuos verta pacituoti. Štai 2-ojo pėstininku Lietuvos kunigaikščio Algirdo pulko vadas mjr. Jonas Laurinaitis pažèrè pačių tikriausių ditirambų: „Kareiviai, kurie buvo išsiųsti ị drausmès batalioną iš pavesto man pulko, grịžo ne tik pataisyti, bet dar ir apmokinti ant tiek, kad [keli] iš jų tapo pastatyti viršininkais. Iš pulkų buvo siunčiami tokie žmonès, kurių nesugebejo suvaldyti kuopų vadai, bet grąžinti iš [Drausmès] bataliono kuo geriausi ir iki šiam laikui veda save ramiai ir net kitus perspeja ir sulaiko nuo visokiausių išsišokimų. Abelnai [apskritai] <...> Drausmès batalionas iki šiam laikui daug padarè ir net galima pasakyti, kad sulaikè ištisas dalis nuo ištvirkimo, kuris buvo pastebimas 1919 metais. " ${ }^{88}$ Jam antrino ir 9-ojo pėstininkų Lietuvos kunigaikščio Vytenio

\footnotetext{
${ }^{86}$ Vyr. ltn. J. Nevronio $1922 \mathrm{~m}$. balandžio 21 d. raporto Vietinės kariuomenès brigados vadui nuorašas // LCVA, f. 507, ap. 6, b. 1815, 1. 78.

871922 m. birželio 19 d. Kariuomenès teismo „tvarkomojo posėdžio“ nutarimo išrašas // LCVA, f. 507, ap. 6, b. 1816, 1. 219.

88 2-ojo pėstininkų Lietuvos didžiojo kunigaikščio Algirdo pulko vado $1922 \mathrm{~m}$. liepos 1 d. raštas Vietinès kariuomenès brigados vadui // LCVA, f. 507, ap. 6, b. 1816, 1. 298.
} 
pulko vadas užtikrintai pareikšdamas, jog „tvirtinimai, kad drausmės batalionas neatlieka savo užduoties ir sugadina kareivius, visai neatitinka tikrenybei“" ${ }^{\text {"89 }}$. Sunku vienareikšmiškai konstatuoti, kas lėmé toki požiūrị - „korporacinis solidarumas“ su nemalonèn patekusiu bataliono vadu ar idealistinis paviršutiniškumas. Tačiau čia vis dèlto reikètų prisiminti plk. V. Grigaliūno-Glovackio ataskaitos po inspekcijos Varniuose $1921 \mathrm{~m}$. ankstyvą rudenị išvadą apie daugelio dalinių vadų piktnaudžiavimą teise siųsti „nesurimtėjusius“ kareivius ị Drausmès batalioną, užuot pirma patiems įdejjus daugiau pastangų auklèjant naujokus. Taigi palankūs pulkų vadų atsiliepimai greičiau galètų būti traktuojami kaip grąžinta savotiška „moralinė skola“"vyr. ltn. J. Nevroniui už konstruktyvų bendradarbiavimą ir savitarpio supratimą. Liepos pradžioje dar sykị buvo apklaustas ir Telšių karo komendantas mjr. S. Rusteika. Jis pats pirmasis ir dažniausiai Vietinès kariuomenès brigados vado nurodymu lankydavosi Varniuose, kai tik dèl „eilinio“ incidento reikèdavo „ištirti padèti““. Tačiau S. Rusteika nuo ankstesnių savo parodymų nenukrypo: teigè artimai su J. Nevroniu nebendravęs, ị jo dalinị savo komendantūros kareivių niekada nesiuntęs, vizitų metu jokios betvarkès nepastebèjęs ${ }^{90}$.

Taigi, vykstant ikiteisminiam tyrimui, kaip rodo išlikę archyviniai dokumentai, buvo surinkta gana daug prieštaringos informacijos. Tačiau per beveik mènesị Kariuomenès teismo valstybės gynèjas Karolis Žalkauskas su pagalbininkais juos atsijojo, jivertino ir parengė kaltinamajj aktą. Pats kaltinamasis visą tą laiką sẻdèjo Karo kalèjime. Tiesa, rugpjūčio pradžioje jis nusiunte pareiškimą Kariuomenès teismo pirmininkui plk. Petrui Šniukštai, prašydamas sankcionuoti jo paleidimą ị laisvę už pasižadejjimą niekur neišvykti ${ }^{91}$. Tačiau po kelių savaičių (rugpjūčio 22 d.), kai, tikètina, P. Šniukšta susipažino su kaltinamuoju aktu, prašymas buvo atmestas (rezoliucija užrašyta ant paties dokumento). Motyvai nebuvo nurodyti. Galima manyti, jog tokị Kariuomenès teismo pirmininko sprendimą lèmé

89 9-ojo pėstininkų Lietuvos kunigaikščio Vytenio pulko vado $1922 \mathrm{~m}$. liepos 12 d. raštas Vietinès kariuomenès brigados vadui // LCVA, f. 507, ap. 6, b. 1816, 1. 297.

90 Mjr. S. Rusteikos 1922 m. liepos 6 d. parodymai Kauno apygardos teismo Telšių apskrities Telšių nuovados tardytojui // LCVA, f. 507, ap. 6, b. 1816, 1. 270.

91 Vyr. ltn. J. Nevronio 1922 m. rugpjūčio 6 d. pareiškimas Kariuomenès teismo pirmininkui // LCVA, f.507, ap. 6, b. 1816, 1. 6. 
vyr. ltn. J. Nevronio tvirtinimai, kad jis esąs visiškai nekaltas, nors valstybès gynèjo apibendrinta tyrimo medžiaga, vertinant logiškai, neleido laikytis tokios bekompromisès pozicijos. Vis dèlto suimtojo perspektyvos teisme neatrodè labai liūdnos, nes jam neketinta inkriminuoti visų anksčiau iškilusių anoniminių insinuacijų apie paslèptas žmogžudystes - faktai nepasitvirtino. Tačiau ir be jų kaltinamojo akto išvados skambëjo grèsmingai. Ikiteisminio tyrimo medžiaga valstybès gynejui leido konstatuoti, kad „Drausmès batalione [buvo] vartojami žiaurūs kankinimai keičiamosios sudeties kareivių, kurie už menkus drausmès prasižengimus [buvo] plakami nagaikomis, diržais, kumštimis, sodinami narvuosna (kletkosna), tam tikrai ịtaisytuose, kur žmogus ịejęs ne tik negali atsisèsti, bet ir laisvai judeti ir stovèti; [kareiviai taip pat buvo] varomi vaikščioti pritūpus žąsies žingsniu su iškeltomis rankomis ir îsikandus katiliuką i dantis, kabinami su užrištomis užpakaly rankomis ant kablio kyboti ir [baudžiami kitomis] panašiomis įstatymais neleistomis bausmėmis"92. Kiekvienas iš šių epizodų buvo pagrịstas konkrečiais pavyzdžiais, nurodant nukentẻjusiuosius ir kitus liudininkus. Taip pat akcentuota, kad „tas bausmes prieš keičiamosios sudèties kareivius vartojo kadro kareiviai viršininkai [puskarininkiai M. K.] ir karininkai, kuriems bataliono vadas Vyr. ltn. Nevronis ne tik nedraude, bet atbulai pats skatino tai daryti, duodamas už tai dovanas" ${ }^{\text {"93 }}$. Be to, paaiškejo, kad labiausiai engiami buvo tie kareiviai, kurie išdrịso pasiskųsti dalini praejusiais metais inspektavusiam KAM atstovui.

Kariuomenès teismas vyr. ltn. J. Nevronio bylą nagrinejjo 1922 m. rugsèjo $30 \mathrm{~d}$. Autentiškų pastebejjimų, perteikdamas tos dienos atmosferą teisme, savo memuaruose pateikè J. Polovinskas-Budrys. Jis dalyvavo posėdyje kaip liudininkas, nes ejjo karinès kontržvalgybos vadovo pareigas ir jo paskirti pareigūnai tyrè situaciją Varniuose. J. Polovinskas-Budrys pripažino: „Pats tardymo nevedžiau, tad ir liudijime nieko ypatingo nepasakiau. “94 Tačiau liudininkų kambaryje turejjo galimybę pasikalbėti su „pora karšto amžiaus leitenantų, tarnavusių drausmès batalione“ (labai tikètina, kad su P. Jurgelevičiumi ir J. Kaironiu), kurie, jo manymu, ir buvo pagrindiniai

\footnotetext{
92 Vyr. ltn. J. Nevronio kaltinamasis aktas, 1922 m. rugpjūčio 17 d. // LCVA, f. 507, ap. 6, b. $1816,1.2-3$.

93 Ten pat.

94 J. Budrys, min. veik., p. 187.
} 
bylos iniciatoriai. Tiedu karininkai teiravosi „seno lapino“ nuomonès apie galimą teismo sprendimą. J. Polovinskas-Budrys su pasididžiavimu aprašè, kaip jis, lyg tikras vokiečių ir rusų karinių ịstatymų žinovas, pakomentavęs J. Nevronio kaltès traktavimo niuansus ir pareiškęs, kad pastarajam greičiausiai bus paskirti keturi mėnesiai kalèti Karo kalejjime, ir, nelaukęs posèdžio baigties, grịžęs „ị savo įstaigą“.

Netrukus susidare kurioziška, netgi komiška, situacija. Pasirodo - atsiminimuose rašè J. Polovinskas-Budrys, - „sprendimas buvo toks, kaip spejjau. Leitenantai nubejgo pas prokurorą protestuoti: esą viskas buvo suaranžuota [sutarta - M. K.] iš anksto, štai kontržvalgybos viršininkas tą sprendimą <...> pasakęs liudininkų kambaryje. Prokuroras majoras K. Žalkauskas ịtikinèjo juos, jog jokio aranžavimo negalejo būti, kad mano numatytas sprendimas tebuvo ilgos praktikos ir Rusijos istatymų

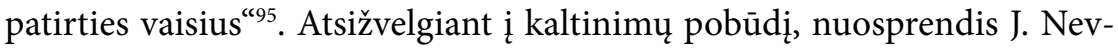
roniui, šiandienos požiūriu, atrodo labai švelnus, juolab kad nuteistajam i bausmès trukmę buvo įskaičiuotas ir arešto laikas ${ }^{96}$. Tačiau dèl to skandalas nekilo. Susidariusią situaciją galima paaiškinti. Pirmojo pasaulinio karo laikotarpio kariuomenèse nepalyginti daugiau reikšmès teikta disciplinos užtikrinimui, o ne tam, kaip tai buvo daroma. Kitaip tariant, iš esmès galiojo principas - tikslas pateisina priemones. Apskritai to meto Lietuvos visuomenès, dar nepamiršusios baudžiavos, neseniai patyrusios brutalią kaizerinès Vokietijos okupaciją ir kitas pokario suirutès negandas, „susigyvenimo“ su prievarta, smurtiniais „auklejimo“ metodais net negalima lyginti su šiandieniniais žmogaus teisių standartais. Tad minèto nuosprendžio logiką, matyt, reikètų suprasti taip: svarbiausia, kad Drausmès batalione kareiviai nebuvo tyčia žudomi, o visa kita - ne taip ir baisu. Vyr. ltn. J. Nevronis bausmès sulaukè tik „už savavalị ịvedimą dẻl prasižengusių kareivių ịstatymais nenumatytų pabaudų priemonès ${ }^{\text {“97. }}$.

Prokurorą K. Žalkauską tokia bylos baigtis netenkino, todèl jis $1922 \mathrm{~m}$. spalio 20 d. pateikè kasacinį skundą aukščiausiajai instancijai - Vyriausia-

\footnotetext{
95 Ten pat.

96 Kariuomenès teismo 1922 m. rugsejjo 30 d. nuosprendis J. Nevronio byloje // LCVA, f. 507 , ap. 6 , b. $1816,1.87$.

97 Mjr. J. Bobelio $1924 \mathrm{~m}$. rugpjūčio $11 \mathrm{~d}$. slapto rašto Teisingumo ministerijai nuorašas // LCVA, f. 930, ap. 2N, b. 55, 1. 32.
} 
jam Tribunolui ${ }^{98}$. Tačiau rašte pats nuosprendis ir jo pagrindimas nebuvo tiesiogiai kvestionuojami - protestuota prieš tam tikrų liudininkų pakvietimą, jų liudijimo tvarką. Vyriausiasis Tribunolas, išnagrinėjęs išdèstytą poziciją, gruodžio $2 \mathrm{~d}$. skundą atmete் ${ }^{99}$. Taigi, ankstesnis Kariuomenès teismo nuosprendis įsigaliojo jau J. Nevroniui faktiškai atlikus bausmę. J. Polovinskas-Budrys atsiminimuose pažymi, jog buvo gana nustebęs, kai šis nuteistas karininkas, atgavęs laisvę, pats pas ji apsilankè ir padèkojo už "gerą liudijimą" ${ }^{100}$. Apibendrindamas visą šią istoriją, kontržvalgybos vadas apie J. Nevronị atsiliepe su tam tikra užuojauta. Esą pastarasis jam padarè „ispūdi gero ir tai ne vidutinio kario, bet tas paskyrimas buvo ne jam. Jis tapo izoliacijos auka. Jis iš bataliono neišeidavo iš baimès, jog kas nors gali atsitikti. Jis tapo ligoniu, jam [buvo] reikalingas gydymas ir poilsis“"101. Jokių dokumentinių tokios J. Nevronio psichologinès būsenos liudijimų nepavyko rasti. Bet jei tikètume posakiu, kad „akys - sielos veidrodis“, vertètų pažvelgti ị tuometę šio karininko portretinę nuotrauką ${ }^{102}$ jo veide tikrai atsispindi kažkokie vidiniai prieštaravimai, dramatizmas. Tolesnis J. Nevronio likimas tai savotiškai ir liudija. Netekęs Drausmès bataliono vado pareigų (dauguma ankstesnių karininkų iš ten taip pat buvo pašalinti) ${ }^{103}$, jis galèjo tarnybą tęsti Pirmajame pasienio pulke. Čia ejo kuopos vado pareigas, kol 1923 m. gruodžio $31 \mathrm{~d}$. buvo perkeltas $\mathfrak{i}$ Inžinerijos pulką, tačiau jau kaip jaunesnysis karininkas. Tai, atrodo, pastūmėjo ji paprašyti išleisti $\mathfrak{i}$ atsargą, bet prieš tai nutare pabandyti išsirūpinti kapitono laipsnị, nes oficialiame prašyme teigè turịs „apie dvejus metus vyresniškumo “104. Pastarojo jo pageidavimo apsvarstyti nesuskubta,

\footnotetext{
98 Kariuomenès teismo valstybès gynèjo K. Žalkausko $1922 \mathrm{~m}$. spalio $20 \mathrm{~d}$. kasacinis skundas Lietuvos Vyriausiajam Tribunolui // LCVA, f.507, ap. 6, b. 1816, 1. 92.

99 Lietuvos Vyriausiojo Tribunolo 1922 m. gruodžio 2 d. sprendimas // LCVA, f. 507, ap. 6, b. 1816, 1. 97.

${ }^{100}$ J. Budrys, min. veik., p. 187.

101 Ten pat, p. 185.

102 Nuotrauka kartu su glausta biografija pateikta knygoje: Lietuvos kariuomenés karininkai 1918-1953, t. 5, Vilnius: Lietuvos nacionalinis muziejus, 2005, p. 339.

103 Žinios apie Drausmès bataliono karininkus, karo valdinininkus ir karo gydytojus, 1923 m. sausio 1 d. // LCVA, f. 763, ap. 1, b. 80, 1. 40.

${ }^{104}$ Vyr. ltn. J. Nevronio $1923 \mathrm{~m}$. gruodžio 8 d. raportas Pirmojo pasienio pulko vadui // LCVA, f. 930, ap. $2 \mathrm{~N}$, b. $55,1.26$.
} 
bet 1924 m. kovo mėnesi J. Nevronis buvo išleistas ị atsargą. Tačiau, vos prabėgus vasarai, šis karininkas vèl raštu kreipèsi, prašydamas grąžinti ji ì kariuomenę, sudaryti galimybę tobulintis Aukštuosiuose karininkų Lietuvos didžiojo kunigaikščio Vytauto kursuose ir suteikti kapitono laipsnị. J. Nevronis aiškino, jog dirbti civilinèse isstaigose net ir gerai mokamą darbą jis nenorįs, nes „negauna moralinio pasitenkinimo“, kurị patirdavo tarnaudamas kariuomeneje, tvirtino dar galèsiąs būti naudingas ${ }^{105}$. Sykiu J. Nevronis pasirūpino pareiškimą sustiprinti dokumentu - puikia savo tarnybos Pirmajame pasienio pulke charakteristika ${ }^{106}$. Nepaisant to, prašymas liko nepatenkintas. Suteikti J. Nevroniui kapitono laipsni nebuvo i̇manoma dèl teistumo ${ }^{107}$. Pasitraukęs iš kariuomenès, jis nemanè kardinaliai keisti savo veiklos, kiek palūkuriavęs - po metų - stojo i̇ policiją. Gali būti, kad toji pertrauka nebuvo atsitiktinè, nes Vidaus reikalų ministerijai, kuriai priklausẻ Piliečių apsaugos (t. y. policijos) departamentas, nuo $1923 \mathrm{~m}$. vidurio iki $1925 \mathrm{~m}$. pradžios vadovavo buvęs J. Nevronio kaltintojas K. Žalkauskas. Tarnybą VRM sistemoje J. Nevronis pradejo Policijos rezervo būrio, skirto neramumams malšinti, vadu, šias pareigas ejo trumpai - vos mėnesi (1925 m. gegužès 13-birželio 16 d.). Vèliau vadovavo Zarasų (tuo metu - Ežerènų) apskrities (1925 m. birželis-1927 m. balandis $)^{108}$, Alytaus miesto (1927 m. balandis-1930 m. rugsèjis) ir - iki išleidimo ị pensiją - Vilkaviškio apskrities (1930 m. rugsẻjis-1931 m. rugsèjis) policijos vadu ${ }^{109}$. Visą tą laiką J. Nevronis neatsisakè siekio grịžti ị kariuomenę. 1926-1929 m. kasmet, o paskutinị kartą 1934 m., būdamas jau keturiasdešimt vienų, jis siuntė atitinkamus prašymus KAM ir net Lie-

\footnotetext{
105 J. Nevronio 1924 m. rugsèjo 16 d. pareiškimas vyriausiajam Lietuvos kariuomenès vadui // LCVA, f. 930, ap. 2 N, b. 55, 1. 35.

${ }^{106}$ Mjr. A. Liutermoza vyr. ltn. J. Nevronị apibūdino taip: „Tarnybą žino gerai, atlieka sąžiningai su pasišventimu. Atsižymi darbštumu, labai drausmingas ir be galo punktuališkas. Moka auklèti kareivius ir sugeba visokiose aplinkybėse palaikyti drausmę ir tvarką. Apie savo pavaldinius rūpinasi. Tvirtos valios ir nepaprastos energijos karininkas." Žr.: Vyr. ltn. J. Nevronio 1923 m. atestacijos pažyma // LCVA, f. 930, ap. 2N, b. 55, 1. 5.

${ }^{107}$ KAM Vyriausiojo štabo Rikiuotes skyriaus $1924 \mathrm{~m}$. birželio 7 d. pranešimas atsargos vyr. ltn. J. Nevroniui // LCVA, f. 930, ap. 2N, b. 55, 1. 26.

108 Vidaus reikalų ministro 1927 m. kovo 29 d. įsakymas Nr. 13 // LCVA, f. 1021, ap. 1, b. $279,1.124$.

${ }^{109}$ Atleisti pensijon // Policija, 1931, Nr. 19, p. 371.
} 
tuvos Respublikos Prezidentui ${ }^{110}$. Tačiau i šias atkaklias pastangas nebuvo atsižvelgta. $1933 \mathrm{~m}$. J. Nevronis nesẻkmingai bandė užsiimti laikraščio „Žinios visiems“ leidyba (prekybos knygomis verslą buvo išbandęs dar jaunystèje - vos baigęs gimnaziją Rygoje), vèliau iki mirties 1940 m. liepos 11 d. dirbo Kaune, skelbimų biure ${ }^{111}$. Taigi „tamsi“ Drausmès bataliono istorija turejjo nemenką ịtaką tolesniam J. Nevronio gyvenimui. Beveik neabejotina, kad iš dalies dèl jos jam nebuvo sudarytos sąlygos tęsti karjeros kariuomenejje.

\section{IŠVADOS}

1. Lietuvos kariuomenès Drausmès bataliono, suformuoto vadovaujantis adaptuotais carinès Rusijos kariniais įstatymais ir dislokuoto Varniuose 1921-1922 m., paskirtis buvo izoliuoti, auklèti ir mokyti nesunkius nusikaltimus padariusius arba politiškai nepatikimus kareivius, kurie ị šị dalinị tęsti tarnybos patekdavo pulko teismo arba - daug dažniau - vien vadų ir kontržvalgybos sprendimu. Perauklejami kareiviai gyveno pagal griežtą dienotvarkę, beveik neturèjo laisvalaikio, privalèjo ne tik išeiti standartinę šauktinių mokymo programą, bet ir dirbti įvairius darbus kareivinių teritorijoje ir už jos ribų.

2. Nors nepriklausomoje Lietuvoje fizinès bausmès nebuvo ịteisintos, Drausmès batalione, sekant carinès Rusijos kariuomenès pavyzdžiu, 1921-1922 m. viduryje ne tik buvo mušama rykštėmis ir panašiais ịrankiais, bet ir sugalvota kitų kankinimams prilygstančių drausminimo būdų (kareivị uždaryti ị ankštą narvą arba pakabinti už surištų rankų ant kablio). Kad susiklostė tokia situacija, didžiausią įtaką turèjo nuošali bataliono dislokacijos vieta ir neigiamos daugelio jo karininkų ir puskarininkių

\footnotetext{
${ }^{110}$ J. Nevronio 1926 m. lapkričio 18 d. pareiškimas KAM // LCVA, f. 930, ap. 2N, b. 55, 1. 18; J. Nevronio 1927 m. rugsejjo 2 d. pareiškimas KAM // Ten pat, 1. 19; J. Nevronio 1928 m. lapkričio 8 d. pareiškimas KAM // Ten pat, 1. 20; J. Nevronio 1929 m. balandžio 5 d. prašymo LR Prezidentui nuorašas // Ten pat, 1. 11; J. Nevronio 1934 m. rugpjūčio 31 d. prašymo LR Prezidentui nuorašas // Ten pat, 1. 41.

${ }^{111}$ Lietuvos kariuomenès karininkai..., t. 5, p. 339.
} 
moralinès savybès.

3. I skundus dèl savivalès Drausmès batalione KAM reagavo operatyviai ir rimtai - inicijavo kelias inspekcijas padéčiai išsiaiškinti. Tyrimas, nepaisant bandymų ji panaudoti asmeninèms sąskaitoms suvesti, neužsitęsè, pagrindinị kaltinamąji - Drausmès bataliono vadą vyr. ltn. J. Nevronị Kariuomenès teismas pripažino kaltu dèl savivalès ir nuteisẻ keturis mènesius kalèti. Greitai J. Nevronis buvo subtiliai priverstas išeiti $\mathfrak{i}$ atsargą, o vèlesni daugkartiniai jo prašymai grąžinti i aktyviąją tarnybą liko nepatenkinti. Drausmès bataliono istorija tapo reikšminga pamoka Lietuvos kariuomenei, padejo jai ateityje išvengti panašaus pobūdžio problemų.

Iteikta $2015 \mathrm{~m}$. spalio $9 \mathrm{~d}$. 


\title{
LE PROBLEME DE L'ARBITRAIRE DANS LE BATAILLON DISCIPLINAIRE DE L'ARMEE LITUANIENNE A VARNIAI EN 1921-1922
}

\author{
Dr. Modestas Kuodys \\ Université Vytautas le Grand
}

Larticle analyse, sur la base de nombreux documents d'archives non publiés, comment on a enquêté sur les faits d'arbitraire du commandement du bataillon disciplinaire de l'armée lituanienne, stationné dans la bourgade reculée de Varniai, en 1921-1922. Cette unité était spécialement destinée à discipliner et former les soldats qui avaient commis divers délits mineurs et les soldats qui nétaient politiquement pas fiables. Un emploi du temps strict, le travail forcé, des exercices physiques et la mise aux arrêts étaient considérés comme des méthodes disciplinaires autorisées. Toutefois, des châtiments corporels (fouet, enfermement dans une cage exiguë, suspension à un crochet avec les mains liées) officiellement non autorisés étaient assez largement pratiqués et se transformaient souvent en humiliation. Le ministère de la Défense en a eu connaissance au milieu de l'année 1921, surtout sous la forme de plaintes anonymes. Il a immédiatement pris des mesures sérieuses pour enquêter sur la situation et la normaliser. Jusqu'au milieu de l'année 1922, se sont rendus à Varniai plusieurs inspecteurs spéciaux qui ont interrogé les victimes et les témoins et rassemblé un grand nombre de données contradictoires. Sur leur base, un procès a été intenté contre le lieutenant J. Nevronis, commandant du bataillon disciplinaire, au tribunal militaire. J. Nevronis a été reconnu coupable d'avoir toléré des mesures disciplinaires non autorisées contre les soldats et il a été emprisonné quatre mois pour cela. Ensuite, il n’a pas pu poursuivre sa carrière dans l'armée. Bien que l'arbitraire au bataillon disciplinaire en 1921- 1922 ne se soit pas transformé en grand scandale public, cela a été incontestablement une bonne leçon pour l'armée lituanienne en formation. Des problèmes à une telle échelle ne se sont plus reproduits plus tard. 


\title{
THE PROBLEM OF LAWLESSNESS IN THE DISCIPLINARY BATTALION OF THE LITHUANIAN ARMY IN VARNIAI, 1921-1922
}

\author{
Dr Modestas Kuodys \\ Vytautas Magnus University
}

Based on abundant and published archival material, the article analyses how the lawlessness of the military leadership in the Disciplinary battalion of the Lithuanian Armed Forces deployed in the remote country town of Varniai in 1921-1922 were investigated. This unit had been specifically intended for disciplining and training politically unreliable soldiers and soldiers guilty of minor offenses. A tight schedule, forced labour, physical fitness exercises and arrest were considered as legitimate discipline methods. At the same time, unsanctioned corporal punishment (beatings, imprisonment in cramped cages, hanging from hooks with tied hands) was widely practiced and formalized, and often turned into open mockery. In the middle of 1921, information about such practices, mainly in the form of anonymous complaints, reached the Ministry of Defence. The Ministry took immediate measures to investigate and normalise the situation. Several special inspectors visited Varniai until the middle of 1922 and questioned the victims and witnesses, and gathered a lot of controversial material. Based on that, criminal proceedings were initiated in court against Lieut. J. Nevronis, the commander of the Disciplinary battalion. Nevronis was found guilty of tolerating the illegal discipline methods of soldiers and he was subsequently imprisoned for four months. This ended his military career. Although the lawlessness in the Disciplinary battalion in 1921-1922 did not turn into a huge public scandal, it was definitely a very serious lesson for the emerging Lithuanian army. A problem of such magnitude did not recur in the future 